\title{
Emer de Vattel and the Externalization of Sovereignty
}

\section{Introduction}

The word "sovereignty" is one of those powerful words which has its own existence as an active force within social consciousness. Through the cognitive process of the human mind, such linguistic signs not only represent and describe reality, but they can also play a leading part in the creation and the transformation of reality. Indeed, they are activities in themselves; they are dynamic mental-social phenomena; they actually exist and act within the shared consciousness of humanity. ${ }^{1}$

In the first quarter of the 20th century, during the accalmie of the Great War, Harold Laski wrote: "Nothing is today more greatly needed than clarity upon ancient notions. Sovereignty, liberty, authority, personality - these are the words of which we want alike the history and the definition; or rather, we want the history because its substance is in fact the definition."' In the last quarter of that century, following the dismemberment of the Soviet Empire, Boutros Boutros-Ghali expressed similar concerns: "A major intellectual requirement of our time is to rethink the question of sovereignty not to weaken its essence, which is crucial to international security and cooperation,

This idea of "shared consciousness of humanity" is borrowed from the moral philosophy of Georg Wilhelm Friedrich Hegel, in particular from G.W.F. Hegel, Phänomenologie des Geistes (Hamburg: Meiner, 1952), first published in 1807, paras 632-671; see also the translation by A.V. Miller, G.W.F. Hegel, Phenomenology of Spirit (Oxford: Clarendon, 1977), at pp. 383-409.

The idea of "consciousness" associated to an ensemble of human beings was suggested by G. Butler, "Sovereignty and the League of Nations" (1920-1921), 1 British Y.B. Int'l L. 35, at p. 42, who discussed the word sovereignty, and more particularly the expression "external sovereignty", by resorting, inter alia, to insights from the new field of psychology. See also P. Allott, "Reconstituting Humanity - New International Law" (1992), 3 European J. Int'1 L. 219, at p. 223, who expressed the following view: "Society exists nowhere else than in the human mind. And the constitution of a given society exists in and of human consciousness, the consciousness of those conceived as its members and its non-members, past and present. Wherever and whenever a structure-systemof human socializing is so conceived in consciousness, there and then a society is conceived - family, tribe, organized religion, legal corporation, nation, State ..." [emphasis added].

2 H.J. Laski, The Foundations of Sovereignty and Other Essays (New York: Harcourt Brace, 1921), at p. 314 [emphasis added]. 
but to recognize that it may take more than one form and perform more than one function." 3

At the heart of these statements lie two fundamental convictions, namely, (i) that the problem of defining sovereignty can be solved, and (ii) that there exist identifiable meanings which can be attributed to sovereignty. ${ }^{4}$ Whether or not consciously, several commentators in international law, as well as in other disciplines, ${ }^{5}$ have indeed based their opinions on these two assumptions. For instance, Lassa Oppenheim once noted that, "there exists perhaps no conception the meaning of which is more controversial

\footnotetext{
${ }^{3}$ B. Boutros-Ghali, "Empowering the United Nations" (1992-93), 71 ForeignAffairs 89, at p. 99 [emphasis added].
}

${ }^{4}$ Until recently, the strict etymology of the word "sovereignty", had been controversial: see A.P. d'Entrèves, The Notion of the State - An Introduction to Political Theory (Oxford: Clarendon Press, 1967), at p. 102. Bertrand de Jouvenel, Sovereignty - An Inquiry Into the Political Good (Indianapolis, U.S.: Liberty Fund, 1997), at p. 203, however, expressed the view that the etymological origin of the word simply concerns the idea of superiority. It has now been demonstrated that "sovereignty" (souverainete in French) appeared in the late 13th century; the oldest reference to the word "sovereignty" in The Oxford Dictionary goes back to the 1290s - see J.A. Simpson and E.S.C. Weiner (eds.), The Oxford English Dictionary, 2nd ed., Vol. 16 (Oxford: Clarendon Press, 1989), at pp. 77-79. The noun was as a derivative of the mid-12th century word "sovereign" (souverain in French), which in turn corresponded to the medieval Latin superanus and, earlier, to the classic Latin superus, that is, "superior:" see A. Truyol Serra, "Souveraineté" (1990), 35 Archives Philo. D. 313, at pp. 314-315; and, T.F. Hoad (ed.), The Concise Oxford Dictionary of English Etymology (Oxford: Clarendon Press, 1986), at p. 451. See also H. Shinoda, Re-examining Sovereignty - From Classical Theory to the Global Age (New York: St. Martin's Press, 2000), at p. 9.

Interestingly, the German language has no equivalent to the word "sovereignty" in English, souveraineté in French, or "Су вернитет" in Russian. The word Obergewalt relates to the authority within a polity; Statshoheit pertains to state dignity (or majesta in Latin), as opposed to state power; and, Statsgewalt refers to the power rather than the dignity of a polity. Therefore, in order to convey the same thing as "sovereignty", the expression Statshoheit und Statsgewalt must be used in German. See J.K. Bluntschli, The Theory of the State, 2nd ed. (Oxford:Clarendon Press, 1892), at p. $494 \mathrm{ff}$.

${ }^{5}$ In political sciences and international relations, for instance, it was once said that, "the concept of sovereignty has been used not only in different senses by different people, or in different senses at different times by the same people, but in different senses by the same person in rapid succession"; see M.R. Fowler and J.M. Bunck, Law, Power, and the Sovereign State - The Evolution and Application of the Concept of Sovereignty(Pennsylvania:Pennsylvania State University Press, 1995), at p. 4. See also V.A. O'Rourke, The Juristic Status of Egypt and the Sudan (Baltimore, US: John Hopkins University Press, 1935), at p. 10, who wrote: "The word sovereignty holds various conflicting connotations and by no means arouses identical patterns in the minds of different students;" and, E.H. Carr, The Twenty Years Crisis, 1919-1939-An Introduction to the Study of International Relations, 2nd ed. (London: Papermac, 1995), at p. 212, who 
than that of sovereignty". 6 James Crawford, for his part, wrote: "The term 'sovereignty' has a long and troubled history, and a variety of meanings." "

However, the problem of defining sovereignty appears circular and can hardly be "solved" finally because language cannot transcend itself. Since Ludwig Wittgenstein," we have indeed learnt that words, although capable of representing and creating reality, are in turn incapable of satisfactorily explaining language - "There can be no such thing as meaning anything by any word." ${ }^{10}$ And this problem haunts, in particular,

opined that sovereignty "was never more than a convenientlabel; and when distinctionsbegan to be made between political, legal and economic sovereignty or between internal and external sovereignty, it was clear that the label had ceased to perform its properfunction as a distinguishing mark for a single category of phenomena" [emphasis added].

${ }^{6}$ L.F.E. Oppenheim, InternationalLaw - A Treatise, Vol. 1, Peace (London: Longmans, Green, 1905), at p. 103.

7 J. Crawford, The Creation of States in International Law (Oxford: Clarendon, 1979), at p. 26.

${ }^{8}$ See L. Henkin, "InternationalLaw: Politics, Values and Functions - General Course on Public International Law" (1989), 216 R.C.A.D.I. 9, at pp. 24-25, who highlighted the problems with the word "sovereignty" as follows: "States are commonly described as 'sovereign', and 'sovereignty' is commonly noted as an implicit, axiomatic characteristic of Statehood. The pervasiveness of that term is unfortunate, rooted in mistake, unfortunate mistake. Sovereignty is a bad word, not only because it has served terrible national mythologies; in international relations, and even in international, law, it is often a catchword, a substitute for thinking and precision. It means many things, some essential, some insignificant; some agreed, some controversial; some that are not warranted and should not be accepted" [footnotes omitted] [emphasis added].

9 See, in particular, L. Wittgenstein, Tractatus Logico-Philosophicus (London: Routledge and Kegan Paul, 1961), at p. 51, where he wrote: "Propositions can represent the whole of reality, but they cannot represent what they must have in common with reality in order to be able to represent it" [emphasis added]. For one to do this, he wrote, one would have to place oneself "outside the world"; ibid. Later, in L. Wittgenstein, Philosophical Investigations (Oxford: Basil Blackwell, 1958), at p. 49, he further dwelled upon this: "One might think: if philosophy speaks of the use of the word 'philosophy'there must be a second-orderphilosophy. But it is not so: it is, rather, like the case of orthography, which deals with the word 'orthography' among others without then being second order" [emphasis added]. See also D.G. Stern, Wittgenstein on Mind and Language (New York and Oxford: Oxford University Press, 1995), at pp. 43-47; and, generally, C. McGinn, Wittgenstein on Meaning - An Interpretation and Evaluation (London and New York: Basil Blackwell, 1984), at p. $6 \mathrm{ff}$.

${ }^{10}$ S.A. Kripke, Wittgenstein on Rules and Private Language-An Elementary Exposition (Cambridge, U.S.: Harvard University Press, 1982), at p. 55. See also R. Read, "What 'There Can Be No Such Thing as Meaning Anything by Any Word' Could Possibly Mean", in A. Crary and R. Read (eds.), The New Wittgenstein (London and New York: Routledge, 2000), 74. Contra, see W.W. Tait, "Wittgenstein and the 'Skeptical Paradoxes"” (1986), 83 J. Philosophy 475. 
abstract ideas encapsulated in words ${ }^{11}$ and, above all, in words of great power and social effect, ${ }^{12}$ such as "sovereignty". A more promising project consists in examining the reality-creating role of words, as instruments of social power within the shared consciousness of humanity.

Furthermore, the second conviction that there exist ascertainable meanings inherent in the word sovereignty is deficient as it fails to take into account the creative and transforming function of words, which is also continuous and continuing, changing in its nature and effects over time. It follows that words like "sovereignty" have their own history, which is not only a history of their changing meaning, their changing definition, but a history of the social effects of their changing meaning. As Philip Allott explained:

As persons and as societies, we are what we were able to be, and we will be what we are now able to be. So it is with the history of words. We are what we have said; we will be what we are now able to say. Words contain social history, distilled and crystallized and embodied and preserved, but available also as a social force, a cause of new social effects. ${ }^{13}$

The project here is to bring out the function that "sovereignty", the word, has played in modelling socially constructed reality and the role it is still playing in the continuous and continuing process of reality-creation, that is, in understanding the world as it is at present and as it might be in the near future.

${ }^{11}$ See, for instance, on the word "law", G. Williams, "The Controversy Concerning the Word 'Law'”, in P. Laslett (ed.), Philosophy, Politics and Society, 1st series (Oxford: Basil Blackwell, 1963), 134; and, A. D’ Amato, "Is InternationalLaw Really 'Law'?” (1985), 79 Northwestern U. L. Rev. 1293; and, on the word "State" (état in French), H.C. Dowdall, "The Word 'State"" (1923), 39 Law Q. Rev. 98; and, J.-P. Brancourt, "Des 'estats' à l'Etat: évolution d'un mot" (1976), 21 Archives Philo. D. 39. For a modern example, see on the word "globalization" or mondialisation, B. Stern, "How to Regulate Globalization?", in M. Byers (ed.), The Role of Law in International Politics - Essays in International Relations and International Law (Oxford: Oxford University Press, 2000), 247; and, E. Hey, "Globalisation and InternationalLaw" (2002), 4 Int'l L. Forum 12. See also, generally,T.D. Weldon, The Vocabulary of Politics (Harmondsworth, U.K.: Penguin, 1953).

12 This point was made by W.B. Gallie, "Essentially Contested Concepts" (1955-56), 56 Proc. Aristotelian Soc. 167, who, dwelling upon the disputed character of some political concepts encapsulated in words, considered inter alia the extremely powerful word "democracy"; id., at p. 183 ff. See also J.N. Gray, "On the Contestability of Social and Political Concepts" (1977), 5 Pol. Theory 331; D. Miller, "Linguistic Philosophy and Political Theory", in D. Miller and L. Siedentop (eds.), The Nature of Political Theory (Oxford: Clarendon Press, 1983), p. 35; and, W.E. Connolly, The Terms of Political Discourse, 3rd ed. (Princeton:Princeton University Press, 1993).

${ }^{13}$ P. Allott, Eunomia - New Order for a New World (Oxford: Oxford University Press, 1990), at p. 9 [emphasis added]. 
This paper is interested in what undoubtedly constitutes the most important episode in this history of the changing social effects of "sovereignty" on the international plane, which followed the explicit introduction the word at hand in the 16th century by Jean Bodin in Les six Livres de la Republique. ${ }^{14}$ Indeed, the historical inquiry concerns the doctrinal contribution of Emer de Vattel, who is considered by many as the father of modern international law $w^{15}$ (although there is a continuing debate as to such "paternity", ${ }^{16}$ not even his harshest critics ${ }^{17}$ deny his seminal role ${ }^{18}$ ). The focus will be on

14 J. Bodin, Les six Livres de la Republique (Paris: Iacques du Puys, 1583), first published in 1576. See also the translation by R. Knolles and J. Bodin, The Six Bookes of a Commonweale (London: Impensis G. Bishop, 1606).

15 The etymological origin of "international law", on the other hand, is credited to the British author Jeremy Bentham, who introduced the expression in his influential book An Introduction to the Principles of Morals and Legislation (London: Pickering, 1823), first published in 1789. See also M.S. Janis, "Jeremy Bentham and the Fashioning of 'International Law'” (1984), 78 American J. Int'l L. 405.

${ }^{16}$ See, among many authors on this controversial issue, F. de Martens, Traité de droit international, Vol. 1 (Paris: Chevalier-Marescq,1883), at pp. 202 and 212; L.F.L. Oppenheim, International Law - A Treatise, Vol. 1, Peace (London: Longmans, Green, 1905), at p. 58; W. Van der Vlugt, "L'CEuvre de Grotius et son influence sur le développement du droit international"(1925), 7 R.C.A.D.I. 395, at pp. 444-445; J.B. Scott, The Spanish Origin of International Law - Francisco de Vitoria and his Law of Nations (Oxford: Clarendon Press, 1934), at p. 281 ff.; M. Bourquin, "Grotius est-il le père du droit des gens?", in Grandes figures et grandes auvres juridiques (Geneva: Librairie de L'Université, 1948), p. 77; P. Haggenmacher, Grotius et la doctrine de la guerre juste (Paris: Presses universitaires de France, 1983), at p. 613 ff.; P. Haggenmacher, "La place de Francisco de Vitoria parmi les fondateurs du droit international", in A. Truylol Serra et al. (eds.), Actualité de la pensée juridique de Francisco de Vitoria (Brussels: Bryulant, 1988), p. 27; and, Y. Onuma, "When was the Law of International Society Born? - An Inquiry of the History of InternationalLaw from an IntercivilizationalPerspective" (2000), 2 J. History Int'l L. 1, at p. 5.

${ }^{17}$ See, for instance, C. van Vollenhoven, The Three Stages in the Evolution of the Law of Nations (The Hague: Martinus Nijhoff, 1919), at p. 32, who was forced to make the following admission: "But the most disheartening fact of all is that Vattel was enormously successful. The man who, as a thinker and a worker, could not hold a candle to Grotius, was so favoured by fortune that the Second Stage of the Law of Nations (from 1770-1914, speaking roughly again) may be safely called after him."

${ }^{18}$ See P. Guggenheim, Emer de Vattel et l'étude des relationsinternationalesen Suisse (Geneva: Librairie de l'Université, 1956), at p. 23, who noted the following about Vattel: "Pourtant, sa contribution au développement du droit international ne saurait être sous-estimée." See also E. Jouannet, Emer de Vattel et l'émergence doctrinale du droit internationalclassique (Paris: Pedone, 1998), at p. 421: “Aussi bien, ceux que l'on a longtemps considéré comme les pères du droit international, que ce soient Grotius ou Pufendorf, Barbeyrac ou Burlamaqui, Rachel ou Textor, ne le sont que de manière indirecte et secondaire alors même que cette paternité longtemps controversée revient sans hésitation, selon nous, à Wolff puis Vattel" [emphasis added]. 
how the word "sovereignty" was used to carry out the externalization of the idea of exclusive and supreme power over territory and people.

Before focussing on the discourse in which Vattel transformed the reality associated with the word "sovereignty", a consideration of his background is appropriate because, as Mallarmé appositely wrote, "the general elements of his biography allow us to explain some of his ideas and the way he presented them to the public."19

\section{Immediate personal context}

The town of Couvet, in the principality of Neuchâtel, is where Emer de Vatte ${ }^{20}$ was born in 1714 and about which he wrote: "I was born in a country of which liberty is the soul, the treasure, and the fundamental law." ${ }^{21}$ The aristocratic background of his family came from both his father, who was a ennobled Protestant minister of the church, and his mother, who was the daughter of the principality's counsel at the Prussian Court. From his tender years, Vattel showed rare talents for the study of sciences and politics; he intended to follow the same vocation as his father. His two older brothers pursued careers in the army. His father passed away in 1730, when Vattel was at the University of Bâle, where he completed a degree in humanities and philosophy with the highest distinction.22

In 1733, Vattel left for Geneva to pursue theological and metaphysical studies. As a teacher, he had Jean-Jacques Burlamaqui, who then held the chair of civil law and natural law. ${ }^{23}$ Hence, "it is very likely that Burlamaqui's lectures allowed him to discover, over philosophy, the doctrines of natural law, political law and the law of

19 A. Mallarmé, "Emer de Vattel", in A. Pillet, (ed.) Les fondateurs du droit international (Paris: Giard and Brière, 1904),481, at p. 483; author's translation of: "les traits généraux de sa biographie permettent d'expliquer certaines de ses idées et la forme sous laquelle il les a présentées au public" [footnotes omitted].

${ }^{20}$ Also spelt "Vatel", or even "Wattel".

${ }^{21}$ E. de Vattel, Law of Nations, infra, note 29, at p. xvii. See also Droit des Gens, Vol. 1, infra, note 29, at p. xxvi: "Je suis né dans un pays, dont la Liberté est l'âme, le trésor and la Loi fondamentale" [spelling modernized].

22 See E. Béguelin, "En souvenir de Vattel”, in Recueil de travaux (Neuchâtel, Switzerland: Attinger, 1929), p. 33; A. de Lapradelle, "Emer de Vattel", in J.B. Scott (ed.), The Classics of International Law - Vattel, Vol. 1 (Washington: Carnegie Institution of Washington, 1916), i at p. iii ff.; and, M. de Hoffmanns, "Notice sur la vie d'Emer de Vattel”, in E. de Vattel, Le droit des gens ou Principes de la loi naturelle appliqués à la conduite et aux affaires des Nations et des Souverains, new ed. (Paris: Aillaud, 1835), 65, at p. 65.

${ }^{23}$ See B. Gagnebin, Burlamaqui et le droit naturel (Geneva: Editions de la Frégate, 1944), at p. 245, who wrote: "Bien qu'il [Vattel] se fût destiné à la théologie, il est extrêmement probable sinon certain qu'il suivit les cours de droit naturel que donnait Burlamaqui." 
nations. ${ }^{.24}$ Soon, Vattel's interests shifted from theology to philosophy and literature, due to the influence of Gottfried Wilhelm Leibnitz's writings and that of Christian Wolff. At the time, every piece by Leibnitz was the subject of learned debates, to which Vattel participated in 1741 with the publication of Défense du système leibnitzien contre les objections et les imputations de Mr de Crousaz ${ }^{25}$ which he dedicated to the king of Prussia, Frederick the Great.

His limited means forced Vattel to offer his services for remuneration, which brought him to Berlin in 1742 where, under the invitation of the French ambassador to Prussia, he sought an appointment to a diplomatic post from Frederick the Great, whose subject he was by birth. None was available at that time and, in pressing need of patronage, he went to Dresden in 1743, where he gained the trust of the Count of Brühl, First Minister of Saxony, who helped him secure employment in the embassy. Given that his functions were light, Vattel spent the bulk of his time at Neuchâtel. ${ }^{26}$ There he wrote a piece on morals and philosophy, Le loisir philosophique; ou Pièces diverses de philosophie, de morale et d'amusement, ${ }^{27}$ published in 1747.

In 1749, Vattel was assigned to Bern as the Minister Plenipotentiary for Saxony, a modest position with its share of frustrations that he occupied until $1758 .{ }^{28}$ It is during these ten years that he wrote his masterpiece, Le Droit des Gens; ou Principes de la loi

${ }^{24}$ E. Béguelin, supra, note 22, at p. 40; author's translation of: "il est assez vraisemblable que les leçons de Burlamaqui lui découvrirent, par-delà la philosophie, les principes du droit de nature, du droit politique et du droit des gens" [footnotes omitted].

${ }^{25}$ E. de Vattel, Défense du système leibnitzien contre les objections et les imputations de Mr de Crousaz, contenues dans l'Examen de l'Essai sur l'homme de Mr Pope; où l'on a joint la Réponse aux objections de Mr Roques, contenues dans le Journal Helvétique (Leyden: Luzac, 1741). According to A. Mallarmé, supra, note 19, at p. 486, it is said to have attracted at once the attention of intellectual circles in Europe because of its rigorous discussion of the voluntary liberty of man.

${ }^{26}$ See E. Béguelin, supra, note 22, at p. 45, who wrote that "ce ne sont pas exclusivement des affaires particulières comme le dit Ostervald, qui ramenèrent ainsi Vattel à Neuchâtel. Dans une autre lettre, ce dernier explique qu'il y est revenu, en attendant que le ministre prît à Dresde les arrangements convenables pour le pourvoir quelque part d'un emploi de conseiller d' ambassade. Cette attente dura trois ans" [footnotes omitted].

27 E. de Vattel, Le loisir philosophique; ou Pièces diverses de philosophie, de morale et d'amusement (Geneva: Walther, 1747). This book was really the publication, with some additions, of an earlier paper entitled Pièces diverses, avec quelqueslettres de morale et d'amusement (Paris: Briasson, 1746).

${ }^{28}$ See E. Béguelin, supra, note 22, at pp. 50-52; C. Phillipson, "Emerich de Vattel", in J. Macdonell and E. Manson (eds.), Great Jurists of the World, Vol. 2 (Boston: Little, Brown, 1914), 477, at pp. 478-479; J. Westlake, Chapters on the Principles of International Law (Cambridge: Cambridge University Press, 1894), at p. 76; and, M. Avenal, "Vattel”, in Nouvelle biographie générale, depuis les temps les plus reculés jusqu’à nos jours, Vol. 45 (Paris: Fermin-Didot, 1860), p. 997. 
naturelle appliqués à la conduite \& aux affaires des Nations \& des Souverains. ${ }^{29}$ At the time of its publication, in 1758, the Seven Years War was raging in Europe, which started two years before when Frederick the Great invaded Augustus III's Saxony after the latter formed an alliance with Maria Theresa of Austria against Prussia over the control of the Province of Silesia. ${ }^{30}$ Evidently impressed by Droit des Gens and requiring competent diplomatic advisors, Augustus III recalled Vattel to Dresden in 1759, appointed him at the Privy Council, and made him chief adviser of the Government of Saxony on foreign affairs. ${ }^{31}$

Contemporaneous to the publication of Droit des Gens, there are several other books, consisting of compilations of political essays many times augmented and reprinted, which can now be attributed to Vattel almost beyond doubt. The original first manuscript is entitled Mémoires pour servir à l'Histoire de notre tems ${ }^{32}$ the second Mémoires pour servir à l'Histoire de notre tems, par rapport à la Guerre anglo-gallicane, ${ }^{33}$ the

${ }^{29}$ The original work was first published in two volumes, in 1758 , with part of the edition bearing London as the place of publication, while another part bore Leyden. A second edition was published in Neuchâtel in 1773, also in two volumes, which contains several hand-written annotations by Vattel. The third edition, published in Amsterdam in 1775, as well as the ones which followed, put these glosses by the author in notes. On the publishing history of Droit des Gens, see A. de Lapradelle, supra, note 22, at pp. lvi-lix; and, A. Mallarmé, supra, note 19, at pp. 488490.

The version used here is the original London one - E. de Vattel, Le Droit des Gens; ou Principes de la loi naturelle appliqués à la conduite \& aux affaires des Nations \& des Souverains, 2 Vols. (London: n.b., 1758) [hereinafter Droit des Gens]. The English translation utilized is that by J. Chitty, E. de Vattel, The Law of Nations; or, Principles of the Law of Nature, applied to the Conduct and Affairs of Nations and Sovereigns (Philadelphia: Johnson Law Booksellers, 1863) [hereinafter Law of Nations].

${ }^{30}$ See, generally, R. Waddington, La guerre de sept ans - Histoire diplomatique et militaire, 5 Vols. (Paris: Firmin-Didot, 1899-1914); and, R.A. Hall, Frederick the Great and his Seven Years War (London: Allen and Unwin, 1915).

${ }^{31}$ See E. Béguelin, supra, note 22, at pp. 57-58. See also A. Mallarmé, supra, note 19, at p. 485, who wrote the following about Vattel's appointment to the Cabinet of Augustus III: "Parvenu enfin au but qu'il avait poursuivi, et mis dans la possibilitéde manifester son aptitude au maniement des affaires politiques, Vattel se livra tout entier à ses hautes fonctions. En 1733 il écrivait avec bonheurà sa famille: 'J'ai la satisfaction de voir que toute la cour, le public et les cours étrangères applaudissent à la confiance que nos souverains me témoignent'.”

${ }^{32}$ E. de Vattel, Mémoires pour servir à l'Histoire de notre tems, par l'Observateur hollandois, rédigez et augmentez par M.D.V. (Frankfort and Leipzig: Aux Dépens de la Compagnie, 1757).

${ }^{33}$ E. de Vattel, Mémoires pour servir à l'Histoire de notre tems, par rapport à la guerre anglogallicane, par l'Observateur hollandois, rédigez et augmentez par M.D.V., 2 Vols. (Frankfort and Leipzig: Aux dépens de la Compagnie, 1757-1758). 
third Mémoires pour servir à l'Histoire de notre tems, où l'on déduit historiquement le droit et le fait de la guerre sanglante qui trouble actuellement toute l'Europe ${ }^{34}$ and the fourth Mémoires pour servir à l'Histoire de notre tems, contenants des réflections politiques sur la guerre présente. ${ }^{35}$

All of these books indicate that they were "par l'Observateur Hollandois, Rédigez et Augmentez par M.D.V", ${ }^{36}$ which would be a pseudonym and an abbreviation. Indeed, most biographists agree that the "Observateur Hollandois" is Jean-Nicholas Moreau (a French avocat, counsellor at the Provence Court), and "M.D.V." is for Mister de Vattel (Monsieur de Vattel in French, which abbreviation is "M." de Vattel). ${ }^{37}$ Another volume only indicates that it was "recueillis du hollandais" Vattel and Moreau ${ }^{39}$ - Mémoires pour servir à l'histoire de notre tems, par rapport à la République des Provinces-Unies. ${ }^{40}$ There are several other of these Mémoires pour servir à l'histoire de notre tems which are attributed to Vattel ${ }^{41}$ most of them bearing the abbreviation "Mr.D.V.". ${ }^{42}$

${ }^{34}$ E. de. Vattel, Mémoire pour servir à l'Histoire de notre tems, où l'on déduit historiquementle droit et le fait de la guerre sanglante qui trouve actuellement toute l'Europe, par l'Observateur hollandois, rédigez et augmentez par M.D.V. (Frankfort and Leipzig: Aux Dépens de la Compagnie, 1758).

35 E. de. Vattel, Mémoire pour servir à l'Histoire de notre tems, contenants des réflections politiques sur la guerre présente, par l'Observateur hollandois, rédigez et augmentez par M.D.V, 3 Vols. (Frankfort and Leipzig: Aux Dépens de la Compagnie, 1758-1759).

${ }^{36}$ That is, by the Holland Observer, drafted and augmented by M.D.V.

37 See, under these titles, the electronic union catalogue COPAC, for Britain and Ireland, at $<$ www.copac.ac.uk/copac>; and the French CCFR, at <www.ccfr.bnf.fr/accdis/accdis.htm >. See also C. Phillipson, supra, note 28, at p. 479, who indicated: "The Lord Acton Library Catalogue suggests that M.D.V. is "Monsieur de Vattel", and a careful consideration of the Preface and the Notes makes this certain."

38 That is, gathered by the Hollander.

39 See, under this title, the catalogue CCFR, at <www.ccfr.bnf.fr/accdis/accdis.htm>.

${ }^{40}$ E. de Vattel and Jacob-Nicolas Moreau, Mémoires pour servir à l'Histoire de notre tems, par rapport à la République des Provinces-Unies, recueillis du hollandois (Frankfort and Leipzig: Aux Dépens de la Compagnie, 1759).

${ }^{41}$ See the catalogue CCFR, at <www.ccfr.bnf.fr/accdis/accdis.htm>.

${ }^{42}$ They include E. de Vattel, Mémoires pour servir à l'Histoire de notre tems, par rapport aux dissentions présentes entre la Grande-Bretagne et la République des Provinces-Unies au sujet des déprédations angloises sur mer, 3 Vols. (Frankfort and Leipzig: Aux Dépens de la Compagnie, 1759-1760);E. de Vattel, Mémoires politiques et militaires pour servir à l'histoire de notre tems, Opérations des armées françoises en Allemagne en 1759, recueillis et publiés par Mr.D.V. (Frankfort and Leipzig: Aux Dépens de la Compagnie, 1760); E. de Vattel, Mémoires politiques et militaires pour servir à l'histoire de notre tems, Opérations des armées impériales et de leurs hauts alliés en 1759, recueillis et publiés par Mr.D.V., 3 Vols. (Frankfort and Leipzig: Aux 
Also during these years, Vattel would have released two other pieces - Poliergie, ou Mélange de littérature et de poësie, ${ }^{43}$ published in 1757, and Mélanges de littérature, de morale et de politique, published in $1760 .{ }^{44}$ The last of his writing appeared in 1762 and is entitled Questions de Droit Naturel, et Observations sur le Traité du Droit de la Nature de M. le Baron de Wolf. ${ }^{45}$ Originally not intended for the public, it was gathered some years before and consists, for the large part, of materials collected by Vattel during the drafting of Droit des Gens ${ }^{46}$ It also includes propositions put forward to rectify errors he identified in the reasoning of Christian Wolff in his Ius Gentium Methodo ${ }^{47}$ which he discussed therein at some length. ${ }^{48}$

The strain of his official functions, made all the more exhausting towards the end of the Seven Years War with the Peace of Hubertsburg in 1763, proved to be too much for Vattel and, suffering from extreme fatigue, he was forced to retire to his native Neuchâtel in 1766. After some rest and medicine, he precipitated his return to Dresden to resume his duties in the autumn of the same year. But it was too early in his convalescence and the following year saw him have a violent relapse and make the trip again to his home district to seek relief. In spite of all the possible medical care and family attention he received, Vattel died in 1767, prematurely at the age of 53, of the complications of a

Dépens de la Compagnie, 1760); and, E. de Vattel, Mémoires pour servir à l'histoire de notre tems, Campagnes du Maréchal duc de Broglie, commendant en chef des armées françoises en Allemagne, 1759-1761 (Frankfort and Leipzig: Aux Dépens de la Compagnie, 1761).

${ }^{43}$ E. de Vattel, Poliergie, ou mélanges de littérature et de poësie (Amsterdam: Arkstée and Merkus, 1757).

${ }^{44}$ E. de Vattel, Mélanges de littérature, de morale et de politique (Neuchâtel: Éditeurs du Journal helvétique, 1760). In 1765, the same work was published again under the following title: E. de Vattel, Amusemens de littérature, de morale et de politique (The Hague: Gosse and Pinet, 1765).

${ }^{45}$ E. de Vattel, Questions de Droit Naturel, et Observationssur le Traité du Droit de la Nature de M. le Baron de Wolf (Berne: Société Typographique, 1762).

${ }^{46}$ See C. Phillipson, supra, note 28, at pp. 479 and 480.

${ }^{47}$ C. Wolff, Ius gentium methodo scientifica pertractatum. In quo ius gentium naturale ab eo, quod voluntarii pactitii, et consuetudinarii est, accurate distincguitur (Frankfurt and Leipzig: n.b., 1764) [hereinafterIus gentium]. See also the French translation from the notes of E. Luzac, C. Wolff, Institutions du Droit de la Nature et des Gens, Dans lesquelles, par une chaîne continue, on déduit de la nature même de l'homme toutes ses obligations et tous ses droits (Leiden: Luzac, 1772); and, the English translation by J.H. Drake, C. Wolff, The Law of Nations Treated According to a Scientific Method - In which Natural Law of Nations is carefully distinguished from that which is voluntary, stipulative and customary (Oxford: Clarendon Press, 1934) [hereinafter Wolff's Law of Nations].

${ }^{48}$ See M. de Hoffmanns, supra, note 22, at p. 67. 
dropsy of the chest. He left his wife that he married at Dresden in 1764 and a son born in $1765 .^{49}$

\section{The discourse in Le Droit des Gens}

This biographical note completed, ${ }^{50}$ the inquiry shall continue by focussing on Vattel's discourse and his use of the word "sovereignty" in Droit des Gens. In its original format, this two-volume work includes (i) a preface, in which the author explains why he wrote the book and what are the guiding principles he intended to follow, (ii) preliminaries, which brush a general picture of the main ideas of the law of nations, and (iii) four books, which constitute the body of the manuscript - the first book on the nation in itself, the second one on the nation and its relation with others, the third one on war, and the last book on peace and embassies. ${ }^{51}$

To a large extent, Vattel came up with his theory of government and his system of international law by transforming the reality that "sovereignty", the word, represents through the cognitive process of the mind within the social consciousness of humanity. Indeed, with this word, Droit des Gens attempted the externalization of power, which was transposed from the internal plane to the international plane. Accordingly, his utilization of sovereignty creates a new reality, that of the exclusivity of authority without.

The first manifestation of an intention to externalize the internal governing authority appears in book one of Droit des Gens, entitled "Of Nations Considered in Themselves". ${ }^{52}$ In spite of the numerous claims that public law was not the focus of the

${ }^{49}$ See, generally,P. Guggenheim, supra, note 18, at p. 11; E. Béguelin, supra, note 22, at pp. 6165 and 138-140, notes 185 and 186; C. Phillipson, supra, note 28, at p. 480; and, A. Mallarmé, supra, note 19, at pp. 485-486. See also A. de Lapradelle, supra, note 22, at p. vi: "La disparition de cet utile diplomate, de ce bon écrivain fut plus profondément ressentie dans le cercle intime de ses amis que dans celui, plus étendu, mais, pour lui, trop large, de la politique ou des lettres, car on l'aimait 'pour la candeur de son âme et la tendresse de son esprit", suivant la jolie formule par laquelle un de ses amis, Hennin, dix-huit mois avant sa mort, le présentait à Voltaire" [footnotes omitted].

${ }^{50}$ It is noteworthy that A. Mallarmé, id., at p. 486, opined that three important elements come out of Vattel's background: "Trois traits saillants se détachent de cette biographie: Vattel a le goût de la philosophie et a étudié à fond, des sa jeunesse, le système de Leibnitz; Vattel est diplomate et connaît les goûts du public instruit des cours Européennes; Vattel est resté citoyen suisse et a conservé son indépendance. Ces différentes particularités nous permettront d'expliquer plusieurs caractères de son oeuvre: philosophe, Vattel la bâtira sur les bases du système qu'il a préconisé; diplomate, il saura l'écrire en un style élégant et dans la forme qui devait plaire aux pesonnes auxquelles il s'adressait; citoyen suisse, il conservera, malgré ses fonctions, l'amour profond de l'indépendance et de la liberté dont jouissiat sa patrie."

51 See A. Mallarmé, supra, note 19, at p. 591.

52 See Law of Nations, at p. 1. See also Droit des gens, Vol. 1, at p. 17. 
manuscript,${ }^{53}$ this book deals extensively with "topics belonging not to international law, but to the distinct science of political or constitutional law concerning the internal government of particular States". ${ }^{54}$ In fact, Vattel looked at three questions, namely, (i) the notion and organization of the sovereign State, (ii) the role of government in the management of State interest, and (iii) the determination of national territory. ${ }^{55}$

The definition of State in the first book ${ }^{56}$ is taken verbatim from the preliminaries, where Vattel proposed the following:

NATIONS or States are bodies politic, societies of men united together for the purpose of promoting their mutual safety and advantage by the joint efforts of their combined strength.

Such a society has her affairs and her interests; she deliberates and takes resolutions in common; thus becoming a moral person, who possesses an understanding and a will peculiar to herself, and is susceptible of obligations and rights. ${ }^{57}$

Such a definition of "State" or "nation" - terms Vattel used interchangeably and viewed as synonymous ${ }^{58}$ - is based on the ideas of "social contract" 59 and "moral

${ }^{53}$ See, for instance, Law of Nations, at pp. 1-2: "We shall not here enter into the particulars; this subject belonging to the public universal law: for the object of the present work, it is sufficient to establish the general principles necessary for the decision of those disputes that may arise between nations"; [emphasis in original]. To the same effect, Vattel wrote in a later chapter of the same book: "The Reader cannot expect to find here a long deduction of the rights of sovereignty, and the functions of a prince. These are to be found in treatises on the public law. In this chapter we only propose to show, in consequence of the grand principles of the law of nations, what a sovereign is, and to give a general idea of his obligations and his rights"; [emphasis added]. Law of Nations, at p. 12. See also Droit des Gens, Vol. 1, at pp. 18 and 39. As well, see A. Malarmé, supra, note 19, at pp. 586-587.

${ }^{54} \mathrm{H}$. Wheaton, History of the Law of Nations in Europe and America - From the Earliest Times to the Treaty of Washington, 1842 (New York: Gould, Banks: 1845), at p. 185.

${ }^{55}$ See A. Mallarmé, supra, note 19, at p. 509.

${ }^{56}$ See Law of Nations, at p. 1; and also Droit des Gens, Vol. 1, at p. 17.

${ }^{57}$ Law of Nations, at p. lv [emphasis in original]. See also Droit des Gens, Vol. 1, at p. 1.

${ }^{58}$ However, see P.P. Remec, The Position of the Individual in International Law According to Grotius and Vattel (The Hague: Martinus Nijhoff, 1960), at p. 172, who pointed out that the terms "State" and "nation" are not always used in Droit des Gens to convey the same idea: "Yet it appears from other places that he [Vattel] understands under the term 'Nation' the body of the people united through the civil compact, while 'State' would refer more to the political organization of that body as the system in which the Nation chose to function in order to achieve its end" [footnotes omitted].

59 Also referred to as "social compact". See Law of Nations, at pp. 1v-lvi: "Nations being composed of men naturally free and independent, and who, before the establishment of civil 
person" ${ }^{60}$ And, most importantly, it would require the recognition of some kind of competence to govern. ${ }^{61}$

Indeed, the public body at the head of such a society of persons coming together to protect shared interests and pursue common goals must have the power to provide order and to rule. ${ }^{62}$ "This political authority is the Sovereignty," wrote Vattel, "and he or they who are invested with it are the Sovereign". ${ }^{63}$ He further explained thus:

It is evident, that, by the very act of the civil or political association, each citizen subjects himself to the authority of the entire body, in every thing that relates to the common welfare. The authority of all over each member, therefore, essentially belongs to the body politic, or State; but the exercise of that authority may be placed in different hands, according as the society may have ordained. ${ }^{64}$

Depending on the locus of power, the moral person in whose hands the authority is placed constitutes a democracy, an aristocracy or a monarchy and, ${ }^{65}$ Vattel opined ${ }^{66}$

societies, lived together in the state of nature, - Nations, or sovereign States, are to be considered as so many free persons living together in the State of nature. It is a settled point with writers on the natural law, that all men inherit from nature a perfect liberty and independence, of which they cannot be deprived without their own consent. In a State, the individual citizens do not enjoy them fully and absolutely, because they have made a partial surrender of them to the sovereign. But the body of the nation, the State, remains absolutely free and independent with respect to all other men, and all other Nations, as long as it has not voluntarily submitted to them" [emphasis in original]. See also Droit des Gens, Vol. 1, at p. 2.

${ }^{60}$ On this, Vattel further wrote: "That society, considered as a moral person, since possessed of an understanding, volition, and strength peculiar to itself, is therefore obliged to live on the same terms with other societies or States, as individualman was obliged, before those establishments, to live with other men, that is to say, according to the laws of the natural society established among the human race, with the difference only of such exceptions as may arise from the different nature of the subjects"; [emphasis in original]. Law of Nations, at p. 1x. See also Droit des Gens, Vol. 1, at pp. 7-8.

${ }^{61}$ See, generally, O. Beaud, "La notion d'État" (1990), 35 Archives Philo. D. 119, at p. $125 \mathrm{ff}$.

${ }^{62}$ See A. Mallarmé, supra, note 19, at p. 509; and, C. Phillipson, supra, note 28, at p. 496.

${ }^{63}$ Law of Nations, at p. 1 [emphasis in original]. See also Droit des Gens, Vol. 1, at p. 17.

${ }^{64}$ Law of Nations, at p. 1. See also Droit des Gens, Vol. 1, at pp. 17-18.

${ }^{65}$ See Law of Nations, at p. 1; and at p. 52: "That moral person resides in those who are invested with the public authority, and represent the entire nation. Whether this be the common council of the nations, an aristocratic body, or a monarch, this conductor and representative of the nation, this sovereign, of whatever kind, is therefore indispensably obliged to procure all the knowledge and information necessary to govern well, and to acquire the practice and habit of all the virtues suitable to a sovereign." See also Droit des Gens, Vol. 1, at pp. 18 and 110.

${ }^{66}$ So Vattel followed the same classification of forms of government used by Bodin, which Wolff had also done in his Ius Gentium; he did not refer to Montesquieu's new classification of 
these "three kinds of government may be variously combined and modified". ${ }^{67}$

Then, the traditional association between the word "sovereignty" and the reality of the supreme and exclusive power over territory and people within was transposed onto the international plane. ${ }^{68}$ This externalization of the competence to govern was first carried out by establishing what constitutes "sovereignty", this time viewed from without:

Every nation that governs itself, under what form soever, without dependence on any foreign power, is a Sovereign State. Its rights are naturally the same as those of any other State. Such are the moral persons who live together in a natural society, subject to the law of nations. To give a nation a right to make an immediate figure in this grand society, it is sufficient that it be really sovereign and independent, that is, that it govern itself by its own authority and laws. ${ }^{69}$

It is already clear that Vattel has here changed the reality represented by "sovereignty" - the word now pertains to the exclusivity of power without. Put another way, authority is vested into a political body which is the sole representative of the people externally and that is not submitted to any foreign State or to any higher law externally. Therefore, Vattel's "sovereignty" relates to a power which is incorporated and independent.

\subsection{Incorporation of power}

The proposition that a society is not merely the sum of persons forming it, but ought to be viewed in terms of an aggregate of individuals, that is, of a corporate body, having its own will and its own finality, considerably predates Vattel ${ }^{70}$ According to Roscoe Pound, the personification of the State can be traced back to Ancient Greece and would be as old as Plato's Republic:

To Plato the city-state was an individual and the characteristics of the individual human soul projected themselves enlarged in the physiognomy of the State. He was

governments as republics, monarchies, and despotisms, introduced in C.-L. de S. Montesquieu, De l'esprit des loix (London: n.b., 1757), first published in 1748.

${ }^{67}$ Law of Nations, at p. 1. See also Droit des Gens, Vol. 1, at p. 18.

${ }^{68}$ See E. Jouannet, supra, note 18, at p. 404, who wrote: "Que Vattel, ensuite, ait ainsi théorisé la notion de souveraineté externe n'empêche pas qu'il ait perçu tout aussi nettement la notion de souveraineté interne, il commence d'ailleurs son grand ouvrage, au livre I, par une théorisation très poussée à l'égard de la souverainetéinterne avant de l'envisager, aux livres suivants, comme pilier de sa construction internationale. On ne veut pas dire non plus que l'on a affaire à deux notions réellement différentes puisqu'il ne s'agit en définitive que des deux faces opposées d'un même concept" [emphasis added].

${ }^{69}$ Law of Nations, at p. 2 [emphasis in original]. See also Droit des Gens, Vol. 1, at p. 18.

${ }^{70}$ See P.P. Remec, supra, note 58, at p. 166. 
not thinking of a moral order among States but of a moral order within the citystate. But the transition in thought was easy and led to ready acceptance of the juristic dogmatic fiction that treated the mass of a population collectively as the equivalent in moral responsibility of an individual man. ${ }^{71}$

Although picked up by the Roman private civil law, it was only in the Middle Ages that the concept of fictitious juridical person resurfaced, initially in domestic public law and then in international law. ${ }^{72}$

\subsubsection{Vattel's predecessors on moral personality of State}

The first reappearance of the doctrine was with the work of Johannes Althusius, who published Politica ${ }^{73}$ in 1603. But it is Thomas Hobbes ${ }^{74}$ who is credited with the medieval rebirth of the theory of moral personality ${ }^{75}$ hinted at in De Cive, ${ }^{76}$ and firmly

${ }^{71}$ R. Pound, "PhilosophicalTheory and InternationalLaw" (1923), 1 Bibliotheca Visseriana 71, at p. 79. See also A.P. d'Entrèves, Natural Law - An Introduction to Legal Philosophy (London: Hutchinson, 1951), at p. 10.

72 On the influence of Roman law for the development of international law concepts, see $\mathrm{H}$. Lauterpacht, Private Law Sources and Analogies of InternationalLaw (With Special Reference to InternationalArbitration) (London: Longmans, Green, 1927), in particular at pp. 23-25.

73 J. Althusius, Politica methodice digesta et exemplis sacris et profanis illustrata (Herborn Nassau: Corvin, 1603). The importance of Althusius theory was brought up by O. Gierke, Johannes Althusius und die Entwicklung der naturrechtlichen Staatstheorien (Breslau: Koebner, 1880). See also E. Jouannet, supra, note 18, at p. 265.

74 Hobbes's Leviathan is said to be "the greatest, perhaps the sole, master-piece of political philosophy written in the English language."; see M. Oakeshott, "Introduction", in T. Hobbes, Leviathan (Oxford: Basil Blackwell, 1946), at p. viii. See also F.H. Hinsley, Sovereignty, 2nd ed. (Cambridge: Cambridge University Press, 1986), at p. 141.

75 See, among many authors on this aspect of Hobbes's work, C.B. Macpherson, The Political Theory of Possessive Individualism - Hobbes to Locke (Oxford: Clarendon Press, 1964), at pp. 17-29; A. Clair, "Aliénation de droits et institution de l'Etat selon Hobbes" (1980), 25 Archives Phil. D. 305; D. Copp, "Hobbes on Artificial Persons and Collective Actions" (1980), 89 PhilosophicalRev. 579; S. Goyard-Fabre, "Le concept de 'persona civilis' dans la philosophiepolitique de Hobbes" (1983), 3 Cahiers Phil. pol. \& jur. 51; L. Jaume, "La théorie de la 'personne fictive' dans le Léviathan de Hobbes" (1983), 33 Rev. française sc. pol. 1009; D. Gauthier, "Hobbes's Social Contrat" (1988), 22 Noûs 71; F. Tinland, Droit naturel, loi civile et souverainetéà l'époque classique (Paris: Presse universitaires de France, 1988), at pp. 123-157; S. Goyard-Fabre, "Loi civile et obéissance dans l'Etat-Léviathan”, in Y.C. Zarka and J. Bernhardt (eds.), Thomas Hobbes - Philosophie première, théorie de la sicence et politique (Paris: Presses universitaires de France, 1990), 289; L. Stephen, Hobbes (Bristol, U.K.: Thoemmes Antiquarian, 1991), at pp. 182-195; A. Ryan, "Hobbes's Political Philosophy", in T. Sorell (ed.), The Cambridge Companion to Hobbes (Cambridge: Cambridge University Press, 1996), 208; and, E. Jouannet, supra, note 18, at p. $265 \mathrm{ff}$. 
established in Leviathan ${ }^{77}$ with the notion of "artificial person". ${ }^{78}$ This political body, in which is vested the authority to govern, is at the heart of Hobbes's thesis:

And in him [the artificial person] consisted the Essence of the Commonwealth; which (to define it), is One Person, of whose Acts a great Multitude, by mutual Covenants one with another, have made themselves every one the Author, to the end he may use the strength and means of them all, as he shall think expedient, for their Peace and Common Defence. ${ }^{79}$

On the attributes of this artificial person, he wrote: "And he that carried this Person, is called SOVEREIGN, and said to have Sovereign Power; and every one besides, his SUBJECT" ${ }^{80}$ With this combination of sovereignty and social contract, Hobbes attempted to theoretically solve the most pressing political problem of 17 th century England ${ }^{81}$ namely, to justify the permanent submission of individuals to the

76 T. Hobbes of Malmesbury, Elementa philosophica de cive (Amsterdam: n.b., 1647), first published in 1642 .

${ }^{77}$ T. Hobbes of Malmesbury, Leviathan, or The Matter, Forme, \& Power of a Common-WealthEcclesiasticall and Civill (London: Green Dragon, 1651) [hereinafter Leviathan].

The word "Leviathan" is a metaphor for the absolute power of Hobbes's State, which is borrowed from a biblical figure personifying an invulnerable sea monster with terrifying power: see the Holy Bible, Old Testament, Book of Job, 41:24-25.

${ }^{78}$ Leviathan, at pp. 80-83 [spelling modernized].

79 Ibid., at p. 88 [emphasis in original] [spelling modernized].

80 Ibid. [emphasis in original] [spelling modernized].

81 The world in which Hobbes lived was one of civil war and public unrest, to which his work wanted to remedy. In fact, several references to civil wars as the main evil to counter may be found in his book, like in the introduction, where he compared sedition to a sickness and civil war to death; see Leviathan, at p. 1. Similarly, in chapter 13, he wrote: "Howsoever, it may be perceived what manner of life there would be, where there were no common power to fear; by the manner of life, which men that have formerly lived under a peaceful government, use to degenerate into, in a civil War"; Leviathan, at 63. Hobbes believed that States, like human beings, are in a perpetual condition of war - even if they do not actually fight, they constantly constitute a mutual destroying menace. States keep "their weapons pointing, and their eyes fixed on one another," he wrote, "in the state and posture of Gladiators"; Leviathan, at p. 63 [spelling modernized]. See also A.A. Rogow, Thomas Hobbes - Radical in the Service of Reaction (New York and London: Norton, 1986), at p. 151 ff.; N. Bobbio, Thomas Hobbes and the Natural Law Tradition (Chicago and London: University of Chicago Press, 1993), at pp. 29-30; and, A.P. Martinich, Thomas Hobbes (London: Macmillan, 1997), at p. $111 \mathrm{ff}$.

Furthermore, the world in which Hobbes wrote was also one of deep political soul searching and profound intellectual chaos. Indeed, given the events surrounding the overthrow of the monarchy in 1646 and the installation of Oliver Cromwell as Lord Protector of England in 1653, people became fundamentally ambivalent and unsure about the theory of organized society. See, 
established order. ${ }^{82}$

Samuel von Pufendorf ${ }^{83}$ further developed the theory of juristic person - what he called persona moralis composita - in his De Iure Naturae et Gentium,$^{84}$ first published in 1672; the novelty being the dissociation of the moral person of the state from the physical person of the ruler..$^{85}$ In fact, he suggested a doctrine of double contracts one among the individuals of the society and one between this social body and the political body, which is the corporate body of the nation. ${ }^{86}$ His definition of the State as

generally, D.L. Smith, "The Struggle for New Constitutional and Institutional Forms", in J. Morrill (ed.), Revolution and Restoration - England in the 1650s (London: Collins and Brown, 1992), 15; J.P. Sommerville, "Oliver Cromwell and English Political Thought", in J. Morrill (ed.), Oliver Cromwell and the English Revolution (London and New York: Longman, 1990), 234; J.P. Kenyon (ed.), The Stuart Constitution 1603-1688-Documents and Commentary, 2nd ed. (Cambridge: Cambridge University Press, 1986), at p. 175 ff.; and, A. Woolrych, Commonwealth to Protectorate (Oxford: Clarendon Press, 1982), at p. $274 \mathrm{ff}$. On the intellectualcontext in which Hobbes developed his theory and the effect that it had on political thought, see the trilogy of articles by Quentin Skinner: Q. Skinner, "History and Ideology in the English Revolution" (1965), 8 Historical J. 152; Q. Skinner, “The Ideological Context of Hobbes's Political Tought" (1966), 9 Historical J. 286; and, Q. Skinner, "Thomas Hobbes and His Disciples in France and England" (1965-66), 8 Comp. St. Society \& History 153.

${ }^{82}$ See P. Allott, “The Courts and Parliament: Who Whom?” (1979), 38 Cambridge L.J. 79, at p. 106: "What he [Hobbes] did was to fuse together sovereignty theory and social contract theory (which also had an ancient and respectable background) to justify submission to established authority."

83 See, generally, M. Villey, "Les fondateurs de l'école du droit naturel moderne au XVIIe siècle" (1961), 6 Archives Phil. D. 72, at pp. 84-90; and, A. Renaut, "Pufendorf Samuel, 1632-1693 - Le Droit de la nature et des gens, 1672", in F. Chatelet, O. Duhamel and E. Pisier (eds.), Dictionnaire des Oeuvres Politiques (Paris: Presses universitaires de France, 1986), 659.

${ }^{84}$ S. von Pufendorf, De iure naturae et gentium libri octo (Amsterdam: Hoogenhuysen, 1688) [hereinafter De iure naturae]. See also the French translation from the notes of J. Barbeyrac, S. von Pufendorf, Le Droit de la Nature et des Gens, ou Système Générale des Principes les plus importants de la Morale, de la Jurisprudence et de la Politique, 2 Vols. (Amsterdam: Kuyper, 1706); and, the English translation by C.H. Oldfather and W.A. Oldfather, S. von Pufendorf, On the Law of Nature and Nations, 2nd ed. (Oxford: Clarendon Press, 1934) [hereinafter Law of Nature].

${ }^{85}$ See O. von Gierke, The Development of Political Theory (New York: Fertig, 1966), at p. 175 ff.; P. Guggenheim, "La souveraineté dans l'histoire du droit des gens - De Vitoria à Vattel", in Mélanges offerts à Juraj Andrassy (The Hague: Nijhorff, 1968), 111, at p. 119; and, P.P. Remec, supra, note 58, at pp. 163 and 170.

${ }^{86}$ See A. Dufour, “Tradition et modernité de la conception pufendorfienne de l'État” (1976), 21 Archives Philo. D. 55, at pp. 66-67; and, E. Jouannet, supra, note 18, at pp. 286-295. 
a moral person, ${ }^{87}$ however, remains highly reminiscent of Hobbes's: ${ }^{88}$

And so the most convenient definition of a State appears to be this: A State is a compound moral person, whose will, intertwined and united by the pacts of a number of men, is considered the will of all, so that it is able to make use of the strength and faculties of the individual members for the common peace and security. ${ }^{89}$

Von Pufendorf also followed the path of Leviathan in holding that sovereignty "is found in every State, and [is the thing] by which, as by the soul, it lives and is animated". 90

\subsubsection{Vattel on moral personality of State}

Now, although it had already resurfaced in the 18th century, it is accurate to say that, "[a]t the time of Vattel no clearcut theory of moral personality was widely accepted". 91 In fact, Albert de Lapradelle argued that it is really only with Vattel-some say ${ }^{92}$ along with Christian Wolff ${ }^{3}$ - that the personality and authority of the ruler become the

87 According to Pufendorf, moral persons are either "simple" or "composite", the latter being formed, like a State, "when several individual men so unite that whatever, by reason of that union, they want or do, is considered as one will, one act, and no more. This takes place when several individuals so subordinate their will to the will of one person, or of a council, that they themselves are willing to recognize, and wish others to regard, whatever that one person has decreed or done, concerning matters pertaining to the nature of that body and agreeable to its end, and the will and action for all"; Law of Nature, at p. 12. See also De iure naturae, at p. 8.

${ }^{88}$ On the influence of Hobbes upon Pufendorf's theory, especially with respect to State personality and sovereignty, see P. Avril, "Pufendorf", in A. Pillet (ed.), Les fondateurs du droit international (Paris: Giard and Brière, 1904), 331, at p. 378; S. Goyard-Fabre, Le droit et la loi dans la philosophie de Thomas Hobbes (Paris: Klincksieck, 1975), at p. 15, note 8; P. Haggenmacher, "L'État souverain comme sujet de droit international, de Vitoria à Vattel" (1992), 16 Droits 11, at pp. 18-19; and, E. Jouannet, supra, note 18, at pp. 284-286.

${ }^{89}$ Law of Nature, at p. 984. See also De iure naturae, at p. 672.

${ }^{90}$ Law of Nature, at p. 1000. See also De iure naturae, at p. 683.

91 P.P. Remec, supra, note 58, at p. 169. See also E. Jouannet, supra, note 18, at p. $299 \mathrm{ff}$.

${ }^{2}$ See, among others, P. Guggenheim, supra, note 85, at pp. 120-121; and, E. Jouannet, id., at p. 255 and 311-316. See also P. Haggenmacher, supra, note 88, at p. 20: "Mais c'est seulement au siècle suivant [18th century] que la qualité de sujet du droit international finit par être théorisée à l'aide de la personne étatique souveraine, entraînant un effacement relatif du problème de la compétence de guerre et du belligérant souverain. Les artisans de cette reformulation sont Wolff et Vattel qui, tout en rendant hommage au prince souverain devenu entre-temps despote éclairé, font de l'Etat souverain le principe structurel décisif de leurs traités sur le droit des gens."

${ }^{93}$ Wolff simply assimilated States to individuals, without explaining the juristic personality of the former in Wolff's Law of Nations, at p. 9: "Nations are regarded as individual free persons living in a State of nature. For they consist of a multitude of men united into a State. Therefore 
personality and authority of the State, as a corporate body representing the citizens. ${ }^{94}$ Here is what Vattel wrote on the juridical person of the State:

A political society is a moral person (Prelim. para. 2) inasmuch as it has an understanding and a will, of which it makes use for the conduct of its affairs, and is capable of obligations and rights. When, therefore, a people confer the sovereignty on any one person, they invest him with their understanding and will, and make over to him their obligations and rights, so far as relates to the administration of the State, and to the exercise of the public authority. ${ }^{95}$

The same idea of artificial moral person, separate from the person of the ruler, whose authority to govern was given by the aggregate of individuals it represents, ${ }^{96}$ is found in chapter four, book one, "Of the Sovereign, His Obligations, and His Rights", ${ }^{97}$ where Vattel further dwelled upon the new reality he wants the word "sovereignty" to represent:

We have said, that the sovereignty is that public authority which commands in civil society, and orders and directs what each citizen is to perform, to obtain the end of its institution. This authority originally and essentially belonged to the body of the society, to which each member submitted, and ceded his natural right of conducting himself in every thin as he pleased, according to the dictates of his own understanding, and of doing himself justice. But the body of the society does not always retain in its own hands this sovereign authority: it frequently intrusts it to a senate, or to a single person. That senate, or that person, is then the sovereign. ${ }^{98}$

This public authority transferred from the people to the nation ${ }^{99}$ must be exercised

since States are regarded as individual free persons living in a State of nature, nations also must be regarded in relation to each other as individual free persons living in a State of nature." See also Ius Gentium, at p. 1. Wolff first made reference to the state as a "person" in C. Wolff, Institutiones juris naturae et gentium, in quibus ex ipsa hominis natura continuonexu omnes obligationes et jura omnia deducuntur(Halle, Germany: Officina Rengeriana, 1754), at p. 533.

${ }^{94}$ A. de Lapradelle, supra, note 22, at p. x.: "Pour la première fois, la personalitéet la souveraineté de l'Etat (paras 3-4) se substituent à la personalité et à la souveraineté du prince." See also P. Guggenheim, supra, note 85, at pp. 119-121; and, E. Jouannet, supra, note 18, at p. 404.

95 Law of Nations, at p. 13. See also Droit des Gens, Vol. 1, at p. 42.

96 See C. Phillipson, supra, note 28, at p. 497.

97 Law of Nations, at p. 12. See also Droit des Gens, Vol. 1, at p. 39.

98 Law of Nations, at p. 12 [emphasis in original]. See also Droit des Gens, Vol. 1, at p. 39.

99 Indeed, Vattel argued that the people transferred the competence to govern in favour of the juridical person of the State. This is different than Rousseau's theory, to the effect that the people continually hold this power, crystallized in a volonté générale, which must be followed by the ruler, who is merely an agent of the people. See J.-J. Rousseau, Du Contrat Social; ou Principes 
according to the "Constitution", 100 which prescribes the "fundamental laws"101 that may limit the power to govern; ${ }^{102}$ of course, those laws cannot be changed by the ruler. ${ }^{103}$ Further, because the authority to govern is rooted in the aggregate of individuals, the people can both reform the government and change the constitution; ${ }^{104}$ it may also rid itself of a tyrannical ruler. ${ }^{105}$

It follows from the incorporation of citizens into this moral person that the primary, in fact the only, agent for securing individual interests is the State, which thus owes its

du Droit Politique (Amsterdam: Marc Michel Rey, 1762), at pp. 20-22; and, also, the translation J.-J. Rousseau, A Treatise on the Social Compact; or the Principles of Political Law (London: n.b., 1764), at pp. 20-22. See also P. Guggenheim, supra, note 56, at p. 22.

100 See Law of Nations, at p. 8: "The fundamental regulation that determines the manner in which the public authority is to be executed, is what forms the constitution of the State. In this is seen the form in which the nation acts in quality of a body politic, - how and by whom the people are to be governed,- and what are the rights and duties of the governors" [emphasis in original]. See also Droit des Gens, Vol. 1, at p. 31.

${ }^{101}$ See Law of Nations, at p. 8: "The Laws are regulations established by public authority, to be observed in society. All these ought to relate to the welfare of the State and of the citizens. The laws made directly with a view to the public welfare are political laws; and in this class, those that concern the body itself and the being of the society, the form of government, the manner in which the public authority is to be exerted, - those, in a word, which together form the constitution of the State, are the fundamental laws" [emphasis in original]. See also Droit des Gens, Vol. 1 , at p. 32 .

${ }^{102}$ See Law of Nations, at pp. 14-15; and also Droit des Gens, Vol. 1, at p. 44.

${ }^{103}$ See Law of Nations, at p. 15; and also Droit des Gens, Vol. 1, at pp. 44-45.

${ }^{104}$ See Law of Nations, at pp. 10-11; and also Droit des Gens, Vol. 1, at pp. 35-36.

${ }^{105}$ See Law of Nations, at p. 17: "As soon as a prince attacks the constitution of the State, he breaks the contract which bound the people to him; the people become free by the act of the sovereign, and can no longer view him but as a usurper who would load them with oppression." See also Droit des Gens, Vol. 1, at p. 48.

This line of thought put forward by Vattel, who earlier spoke of the governing authority as the "depositary of the empire" (see Law of Nations, at p. 14; see also Droit des Gens, Vol. 1, at p. 43) is analogous to Locke's theory of government, according to which the supreme governmental authority (i.e. the legislative power) is held in trust by those who rule and return to the people if the trust is broken. See J. Locke, Two Treatises of Government (London: Amen-Corner, 1690), at pp. 369-370: "Though in a constituted commonwealth, standing upon its own Basis, and acting according to its own nature, that is, acting for the preservation of the Community, there can be but one Supreme Power, which is the Legislative, to which all the rest are and must be subordinate, yet the Legislative power being only a Fiduciary Power to act for certain ends, there remains still in the People a Supreme Power to remove or alter the Legislative, when they find the Legislative act contrary to the trust reposed in them". 
principal duty to itself, that is, to its people. ${ }^{106}$ Accordingly, Vattel explained that "a moral being is charged with obligations to himself", ${ }^{107}$ and these are essentially " $t o$ preserve and to perfect his own nature". ${ }^{108}$ The preservation of a nation is its survival and that of its members; the perfection of a nation is the happiness of its people. "The end or object of civil society is to procure for the citizens whatever they stand in need of for the necessities, the conveniences, the accommodation of life, and, in general, whatever constitutes happiness, - with the peaceful possession of property, a method of obtaining justice with security, and, finally, a mutual defence against all external violence.".109

The personification of the State as the representative of an aggregate of individuals is also the basis on which Vattel justified the rejection, already alluded to in the preface, ${ }^{110}$ of patrimonial kingdoms, that is, of kingdoms based on the idea of monarchical ownership ${ }^{111}$ - "the end of patrimony is the advantage of the possessor, whereas the

106 See D.G. Lang, Foreign Policy in the Early Republic - The Law of Nations and the Balance of Power (Baton Rouge and London: Louisiana State University Press, 1985), at p. 17; and, A. Mallarmé, supra, note 19, at p. 513: "Mais ce souverain n'est établi que pour le bien commun de tous les citoyens. Il représente la Nation en ce qu'il devient le sujet où résident les obligations et les droits relatifs à la personne morale de la société politique; par suite, ses devoirs et ses droits sont ceux même de cette nation concernant sa conservation et sa perfection."

107 Law of Nations, at p. 4. See also Droit des Gens, Vol.1, at p. 23.

${ }^{108}$ Law of Nations, at p. 4 [emphasis in original]. See also Droit des Gens, Vol. 1, at p. 23.

109 Law of Nations, at p. 4 [emphasis in original]. See also Droit des Gens, Vol. 1, at pp. 23-24. In most of the remaining of the first book of Droit des Gens, Vattel regrouped under three headings the functions of government flowing from these two obligations. First, to provide for the necessities of the nation (chapter six), which includes also the cultivation of the soil (chapter seven), commerce (chapter eight), the care of the public ways and of tools (chapter nine), as well as money and exchange (chapterten). The second duty of the State is to procure the true happiness of a nation (chapter eleven), which includes also piety and religion (chapter twelve), as well as justice and polity (chapter thirteen). Finally, the last function of government is to fortify itself against external attacks (chapter fourteen), which includes also the question of the glory of a nation (chapter fifteen), the protection sought by a nation, and her voluntary submission to a foreign power (chapter sixteen), how a nation may separate herself from the State of which she is a member, and renounce her allegiance to her sovereign when she is not protected (chapter seventeen), and the establishment of a nation in a country (chapter eighteen). See also F.S. Ruddy, International Law in the Enlightenment - The Background of Emerich de Vattel's Le Droit des Gens (Dobbs Ferry, U.S.: Oceana Publications, 1975), at pp. 146-165;A. Mallarmé, supra, note 19; at pp. 516-533; and C. Phillipson, supra, note 28, at pp. 498-502.

110 See Law of Nations, at p. xiii; and also Droit des Gens, Vol. 1, at p. xvi.

111 See A. Nussbaum, A Concise History of the Law of Nations (New York: Macmillan, 1950), at p. 157. Earlier, the author wrote, id., at p. 128: "Treaties of the medieval type, by which a prince, in one way or another, might dispose of his territory, are still found in this period", that is, during 
prince is established only for the advantage of the State". ${ }^{112}$ Further, given that "the care of their own safety, the right to govern themselves, still essentially belong to the society", ${ }^{113}$ it follows that "true sovereignty is, in its own nature, unalienable". ${ }^{114}$ Put another way, the authority to govern being but a transfer from the individuals in society to the moral person of the State, the latter cannot dispose of the territory on which the people live without its consent. ${ }^{15}$ Another consequence is that, if a ruler has the right to choose his or her successor, it must be "by virtue of the power with which he is, either expressly or by tacit consent, intrusted". ${ }^{116}$

The idea of moral person representing the people is also found in book three of Droit des Gens dealing with war, which Vattel defined as "that State in which we prosecute our right by force". ${ }^{117}$ As one author pointed out, it is in the context of war that, indeed, the juridical person first found applications to international relations in the Middle Ages ${ }^{118}$ For his part, Vattel started by drawing a distinction between, ${ }^{119}$ (i) public war, "that which takes place between nations or sovereigns, and which is

the 18th century. See also, generally,C. Lavialle, "De la fonction du territoire et de la domanialité dans la genèse de l'État en France sous l'ancien régime" (1992), 15 Droit 19.

The principle of patrimonial kingdoms, based on a proprietary right of the ruler over the territory he or she controls, was defended by several author, including Christian Wolff (referred to in the preface, see Droit des Gens, Vol. 1, at p. xvi, and also Law of Nations, at p. xiii) and Hugo Grotius - see Law of Nations, at p. 30: "I know that many authors, and particularly Grotius, give long enumerations of the alienations of sovereignties. But the examples often prove only the abuse of power, not the right. And besides, the people consented to the alienation, either willingly or by force" [footnotes omitted]; see also Droit des Gens, Vol. 1, at pp. 70-71. See also J.L. Brierly, The Law of Nations - An Introduction to the International Law of Peace, 6th ed. (Oxford: Clarendon Press, 1963) at p. 39; and, E. Jouannet, supra, note 18, at pp. 316-318.

112 Law of Nations, at p. 25. See also Droit des Gens, Vol. 1, at p. 59.

${ }^{113}$ Ibid.

${ }^{114}$ Law of Nations, at p. 30. See also Droit des Gens, Vol. 1, at p. 70.

${ }^{115}$ Chapter 21 of book one deals with the question of the alienation of a part of the State. Vattel opined that only in extreme cases of necessity, should such a dismemberment of territory be done (including alienations made by a treaty of peace; see Law of Nations, at pp. 432-434; and also Droit des Gens, Vol. 2, at pp. 257-259). Although valid between the States involved, the provinces or cities thus abandoned are not obliged to accept their new master. See Law of $\mathrm{Na}$ tions, at pp. 118-119; and also Droit des Gens, Vol. 1, at pp. 229-231.

116 Law of Nations, at p. 30. See also Droit des Gens, Vol. 1, at p. 69.

${ }^{117}$ Law of Nations, at p. 291 [emphasis in original]. See also Droit des Gens, Vol. 2, at p. 1.

${ }^{118}$ See P. Haggenmacher, supra, note 88, at p. 13.

${ }^{119}$ It is worth mentioning that Vattel briefly addressed another type of war, namely, civil war, in chapter eighteen of book three; see Law of Nations, at pp. 421-427; see also Droit des Gens, Vol.

2, at pp. $238-248$. 
carried on in the name of the public power, and by its order"120 and, (ii) private war, between private individuals, ${ }^{121}$ the right of which is deemed extinguished by the social contract through which the individuals transferred authority to provide order and rule to the moral person of the State. ${ }^{122}$

Further, the natural rights of individuals to use force for their personal preservation are deemed to pass to the State, not only to administer justice and peace between citizens within, ${ }^{123}$ but also to defend the nation against outside threats. ${ }^{124}$ Such a transfer of power to declare and make war appears clearly from this passage:

Thus the sovereign power alone is possessed of authority to make war. But, as the different rights which constitute this power, originally resident in the body of the nation, may be separated or limited according to the will of the nation (Book I. paras 31 and 45), it is from the particular constitution of each State, that we are to learn where the power resides, that is authorized to make war in the name of the society at large. ${ }^{125}$

Also, given that a State represents its people, a declaration of war means that, not only the nations, but "all the subjects of the one are enemies to all the subjects of the other". ${ }^{26}$

Now, for the present discussion, the most important feature in Vattel's theory is that the power to govern for the benefit of the people - power referred to by using the word

${ }^{120}$ Law of Nations, at 291. See also Droit des Gens, Vol. 2, at 1.

121 On the notion of private war developed by medieval authors, see P. Haggenmacher, supra, note 88 , at pp. 13-14.

${ }^{122}$ See supra, at footnotes 95-105 and accompanying text. See also on this point C. Phillipson, supra, note 28 , at p. 503.

${ }^{123}$ See Law of Nations, at p. 292; and also Droit des Gens, Vol. 2, at p. 2. On the administration of justice internally, see also chapter thirteen, book one - Law of Nations, at p. $77 \mathrm{ff}$; ; and also Droit des Gens, Vol. 1, at p. $153 \mathrm{ff}$.

Similarly, as regards disputes between an individual and a foreigner, the States must represent and protect the interests of their citizens. See Law of Nations, at p. 292: "If a private person intends to prosecute his right against the subject of a foreign power, he may apply to the sovereign of his adversary, or to the magistrates invested with the public authority: and if he is denied justice by them, he must have recourse to his own sovereign, who is obliged to protect him. It would be too dangerous to allow every citizen the liberty of doing himself justice against foreigners; as, in that case, there would not be a single member of the state who might not involve it in war." See also Droit des Gens, Vol. 2, at pp. 2-3.

124 See F.S. Ruddy, supra, note 109, at p. 217, who wrote: "With the formation of society these rights passed from the individual to society, and in society, the right to make war was in the sovereign." See also D.G. Lang, supra, note 106, at p. 18.

125 Law of Nations, at p. 292 [emphasis added]. See also Droit des Gens, Vol. 2, at p. 3.

${ }^{126}$ Law of Nations, at p. 322. See also Droit des Gens, Vol. 2, at p. 59. 
"sovereignty" - is solely in the hands of this "moral person", who will exercise it both within and without, that is, both internally on the state territory and externally on the international plane. This is how he explained the exclusive authority of the state government to represent and act on behalf of the people:

The sovereign, or conductor of the State, thus becoming the depositary of the obligations and rights relative to government, in him is found the moral person, who, without absolutely ceasing to exist in the nation, acts thenceforwards only in him and by him. Such is the origin of the representative character attributed to the sovereign. He represents the nation in all the affairs in which he may happen to be engaged as a sovereign. ${ }^{127}$

The State is thus the incorporated body that absorbs the individuals that form society and represents them not only for domestic matters, but also for matters involving foreign persons or foreign nations. ${ }^{128}$ As far as international affairs are concerned, one author wrote, "[t]he sovereign State and not the individual man are henceforth the criterion by which all relations in the international sphere are judged". ${ }^{129}$

\subsection{Independence of power}

Moreover, in order to assure that the incorporated body of the nation will be the only representative of the people, both within and without, Vattel put forward the idea of

${ }^{127}$ Law of Nations, at p. 13 [emphasis added]. See also Droit des Gens, Vol. 1, at p. 42.

${ }^{128}$ On this point, it is interesting to bring up the analogy suggested by Thomas Franck between the former legal status of women and individuals in their respective legal orders. He wrote: "Just as in domestic law a woman had been, until the 19th century, a 'femme couverte', incapable of acquiring rights in her own name, so all persons in international law remained, until the twentieth century, essentially, 'persons couverts' under the Vattelian system that recognized the rights only of sovereign States"; see T.M. Franck, "Individuals, Groups and States as Rights Holders in International Law", in Canadian Council on International Law, The Impact of International Law on the Practice of Law in Canada - Proceedings of the 27th Annual Conference of the Canadian Council on International Law, Ottawa, October 15-17, 1998 (The Hague: Kluwer Law International, 1999), 62, at p. 64. See also K. Knop, "Feminist Re/Statements: Feminism and State Sovereignty in International Law" (1993), 3 Transna'l L. \& Contemporary Pr. 293, at pp. 323328.

${ }^{129}$ P.P. Remec, supra, note 58, at p. 180. See also P. Haggenmacher, supra, note 88, at pp. 11-12: "Or, durant la période en question, l'Etat souverain est, d'une part, pleinement constitué et, d'autre part, le principal, sinon l'unique sujet du droit international".

For contemporary arguments challenging this international orthodoxy, see M. Noortmann, "Globalisation, Global Governance and Non-State Actors: Researching Beyond the State" (2002), 4 Int'l L. Forum p. 36; and also, L.Y. Fortier, "The Emerging Importance of Non-State Actors in International Law", communication given at the Third Annual International Law Conference of the Canadian Bar Association, Ottawa, Canada, 30 and 31 May 2002. 
State independence, which had already been introduced in the preface, where he wrote that "[e]ach sovereign State claims, and actually possesses an absolute independence on all the others". ${ }^{130}$ In the preliminaries, an analogy about independence was made between the situations of men in society and of nations in the society of nations:

Nations being free and independent of each other, in the same manner as men are naturally free and independent, the second general law of their society is, that each nation should be left in the peaceable enjoyment of that liberty which she inherits from nature. The natural society of nations cannot subsist, unless the natural rights of each be duly respected. ${ }^{131}$

When concluding chapter three of book one, dealing with the constitution of a nation, Vattel also made it clear that "no foreign power has a right to interfere" 132 in matters of national concern.

\subsubsection{Non-intervention}

However, it is in the second book of Droit des Gens, entitled "Of a Nation Considered in Its Relation to Others", ${ }^{133}$ that this principle of State independence was developed. ${ }^{134}$ On the international plane, it would mean that the moral person entrusted by the people ought to be able to govern without the interference of foreign public authorities or individuals. From this idea of State independence, Vattel laid down the general rule prohibiting interference in the internal affairs of a nation:

It is an evident consequence of the liberty and independence of nations, that all have a right to be governed as they think proper, and that no State has the smallest right to interfere in the government of another. Of all the rights that can belong to a nation, sovereignty is, doubtless, the most precious, and that which other nations ought the most scrupulously to respect, if they would not do her as injury. ${ }^{135}$

It comes out clearly from this passage that Vattel has now transformed the reality that the word "sovereignty" represents by associating it with this other word, independence, which would refer to a normative prescription according to which, on the international plane, one State ought not to interfere in the domestic government of another.

This forcefully illustrates how Droit des Gens carried out the externalization of "sovereignty" by providing that the State is the sole holder of authority without as well

${ }^{130}$ Law of Nations, at p. xiii. See also Droit des Gens, Vol. 1, at p. xvii.

${ }^{131}$ Law of Nations, at p. 1xi [emphasis in original]. See also Droit des Gens, Vol. 1, at p. 9.

${ }^{132}$ Law of Nations, at p. 12. See also Droit des Gens, Vol. 1, at p. 38.

${ }^{133}$ Law of Nations, at p. 133. See also Droit des Gens, Vol. 1, at p. 255.

${ }^{134}$ See J.L. Brierly, supra, note 111, at p. 38, who opined that the system proposed by Vattel put an "exaggerated emphasis on the independence of States".

135 Law of Nations, at p. 154 [emphasis added]. See also Droit des Gens, Vol. 1, at p. 297. 
as within. Indeed, Vattel's juridical person does not only have the exclusive power among other internal authorities to represent and rule its people within the territory, but it also has the exclusive power among other public authorities outside (that is, other States) to represent and rule its people within the said territory. This is, of course, in addition to the exclusive power to represent and rule its people in their relations with foreign States and individuals just discussed. Such a use of the word "sovereignty" is thus really a question exclusivity of authority.

Given that foreign nations cannot interfere in the internal government of another nation by virtue of the principle of State independence, "it is not difficult to prove that the latter has a right to oppose such interference". ${ }^{136}$ Indeed, "a sovereign has a right to treat those as enemies who attempt to interfere in his domestic affairs otherwise than by their good offices". ${ }^{137}$ However, this broad rule of non-intervention does not apply in the case of a domestic struggle amounting to a full scale civil war - "every foreign power has a right to succour an oppressed people who implore their assistance". ${ }^{138}$ Although this exception appears in blatant contradiction of the theory of independence, ${ }^{139}$ it is founded on the State practice of the time; ${ }^{140}$ Vattel was "simply stating, nay, strictly limiting, the international usage of the eighteenth century, when [he] conferred upon a nation the right to aid a rebel or his government, - a right as real then as that of ambassadorial inviolability is now". ${ }^{141}$

Likewise, the independence that enjoys this moral person representing the people also means that with respect to religious matters, the State is not submitted to any authority within or without. ${ }^{142}$ Domestically, it was established in Chapter twelve of

\footnotetext{
136 Law of Nations, at p. 156. See also Droit des Gens, Vol. 1, at p. 300.

137 Ibid.

${ }^{138}$ Law of Nations, at p. 155. See also Droit des Gens, Vol. 1, at p. 298.
}

139 See F.S. Ruddy, supra, note 109, at pp. 182-184. See also A. Mallarmé, supra, note 19, at p. 545: "Mais, après avoir posé le principe de non-intervention et après en avoir indiqué les principales applications, il y apporte de telles restrictions que le principe s'en trouve entièrement ébranlé."

${ }^{140}$ See G. Butler and S. Maccoby, The Development of InternationalLaw (London: Longmans, Green, 1928), at pp. 71-72; and, D.G. Lang, supra, note 106, at p. 32: "Such demands for intervention on the grounds of aiding the just cause in a civil war were not unique to Americans, in the [eighteenth century and] nineteenth century the French revolutionaries, Napoleon, and Metternich made similar arguments."

${ }^{141}$ P.H. Winfield, “The History of Intervention in InternationalLaw” (1922-1923), 3 British Y.B. Int'1 L. 130, at p. 137.

${ }^{142}$ On this issue of the authority of the state over religious matters, see A. Mallarmé, supra, note 19, at pp. 522-526; and, C.G. Fenwick, "The Authority of Vattel”, Part I (1913), 7 American Pol. Sc. Rev. 395, at p. 399: "This call for abject submission on the part of the clergy is followed by a vigorous denunciation of the papacy as an institution claiming to be independent of state control." 
book one, entitled "Of Piety and Religion", ${ }^{143}$ that when religion is "publicly established, it is an affair of State" 144 and that the "establishment of religion by law, and its public exercise, are matters of State, and are necessarily under the jurisdiction of the political authority". ${ }^{145}$ But externally too, the State has exclusive authority over religious matters, free from the interference of the Pope or the Emperor ${ }^{146}$ - "It is, then, certain that we cannot, in opposition to the will of a nation, interfere in her religious concerns, without violating her rights, and doing her an injury". ${ }^{147}$

Also linked to the principle of State independence and how Vattel used the word "sovereignty" to represent the reality of this artificial person's exclusive authority to govern and represent the aggregate of individuals in society is the so-called "offices of humanities between nations". ${ }^{48}$ These altruistic obligations were alluded to in the preliminaries, ${ }^{149}$ and are the object of the first chapter of the second book of Droit des Gens. ${ }^{150}$ Extrapolating on the State's duties of self-preservation and self-perfection, ${ }^{151}$ these offices of humanities between nations "consist, generally, in doing every thing in our power for the preservation and happiness of others, as far as such conduct is reconcilable with our duties towards ourselves". ${ }^{152}$

Accordingly, State should, inter alia, help others in case of famine, ${ }^{153}$ favour external trade ${ }^{154}$ avoid monopolizing commerce,${ }^{155}$ assist in opposing a powerful enemy, ${ }^{156}$

\footnotetext{
143 Law of Nations, at p. 55; see also Droit des Gens, Vol. 1, at p. 116.

144 Law of Nations, at p. 56 [emphasis in original]. See also Droit des Gens, Vol. 1, at p. 117.

${ }^{145}$ Law of Nations, at pp. 56-57. See also Droit des Gens, Vol. 1, at p. 118.
}

${ }^{146}$ See Law of Nations, at p. 157: "The general and absolute authority of the pope and council is absurd in every other system than that of those popes who strove to unite all Christendom in a single body, of which they pretended to be the supreme monarchs" [footnotes omitted]. See also Droit des Gens, Vol. 1, at p. 301.

147 Law of Nations, at p. 157. See also Droit des Gens, Vol. 1, at p. 302.

${ }^{148}$ Law of Nations, at p. 133. See also Droits des Gens, Vol. 1, at p. 255. See also E. Jouannet, supra, note 18, at pp. 146-151.

${ }^{149}$ See Law of Nations, at p. 1xi: "each individual nation is bound to contribute every thing in her power to the happiness and perfection of all the others" [emphasis in original] [footnotes omitted]. See also Droit des Gens, Vol. 1, at p. 8.

${ }^{150}$ Droit des Gens, Vol. 1, at p. $255 \mathrm{ff}$; and also Law of Nations, at p. $133 \mathrm{ff}$.

151 See supra, at footnotes 108-109 and accompanying text.

152 See Law of Nations, at p. 134; and also Droit des Gens, Vol. 1, at p. 258.

153 See Law of Nations, at p. 136; and also Droit des Gens, Vol. 1, at pp. 260-261.

${ }^{154}$ See Law of Nations, at p. 143; and also Droit des Gens, Vol. 1, at pp. 274-275.

155 See Law of Nations, at p. 144; and also Droit des Gens, Vol. 1, at pp. 276-277.

156 See Law of Nations, at p. 154; and also Droit des Gens, Vol. 1, at pp. 296-297. 
cooperate for the administration of justice, ${ }^{157}$ et cetera. ${ }^{158}$ However, these obligations to assist others in their preservation and perfection are only secondary because the duties that a nation owes to itself must first be fulfilled. ${ }^{159}$ In that regard, and intertwined with the idea of independence, Vattel had made the following remark in the preliminaries:

As a consequence of that liberty and independence, it exclusively belongs to each nation to form her own judgment of what her conscience prescribes to her, - of what she can or cannot do, - of what it is proper or improper for her to do: and of course it rests solely with her to examine and determine whether she can perform any office for another nation without neglecting the duty which she owes to herself. In all cases, therefore, in which a nation has the right of judging what her duty requires, no other nation can compel her to act in such or such particular manner: for any attempt at such compulsion would be an infringement on the liberty of nations..$^{160}$

Also linked to the idea of independence is that a nation cannot force its offices of humanities upon another. ${ }^{161}$ In fact, "every nation being free, independent, and sole arbitress [sic] of her own actions, it belongs to each to consider whether her situation warrants her in asking or granting any thing on this head". ${ }^{162}$

The principle of equality of States proposed by Vattel ${ }^{163}$ - in the preliminaries ${ }^{164}$ and in chapter three of book two ${ }^{165}$ - is founded as well on State independence and the attribute of the moral person, representative of the people, to decide for itself how to best govern the nation. From the inability of any State to interfere in the internal gov-

See Law of Nations, at p. 162; and also Droit des Gens, Vol. 1, at pp. 311-312.

158 See, generally, A. de Lapradelle, supra, note 22, at pp. xii-xiii; C. Phillipson, supra, note 28, at pp. 502-503; and, P.F. Butler, "Legitimacy in a States-System: Vattel's Law of Nations", in M. Donelan (ed.), The Reason of States - A Study in International Political Theory (London: Allen and Unwin, 1978), 45, at p. 51.

159 See the preliminaries in Law of Nations, at p. 1xi: "But the duties that we owe to ourselves being unquestionably paramount to those we owe to others, - a nation owes herself in the first instance, and in preference to all other nations, to do every thing she can to promote her own happiness and perfection." See also Droit des Gens, Vol. 1, at p. 8. On this issue, see the author G. Gidel, "Droits et devoirs des Nations - La théorie classique des droits fondamentaux des États" (1925), 10 R.C.A.D.I. 537, at p. 582; P.P. Remec, supra, note 58, at pp. 141-142; and, P.F. Butler, supra, note 158, at p. 53.

${ }^{160}$ Law of Nations, at pp. 1xi-lxii [emphasis in original]. See also Droit des Gens, Vol. 1, at p. 9.

161 See Law of Nations, at pp. 136-137; and also Droit des Gens, Vol. 1, at pp. 262-263.

162 Law of Nations, at p. 137. See also Droit des Gens, Vol. 1, at pp. 263-264.

163 Interestingly, J.L. Brierly, supra, note 111, at p. 37, once wrote about Vattel's doctrine of State equality that it was "a misleading deduction from unsound premisses".

164 See Law of Nations, at pp. 1xii-1xiii; and also Droit des Gens, Vol. 1, at pp. 11-12.

165 See Law of Nations, at p. 148 ff.; and also Droit des Gens, Vol. 1, at p. $285 \mathrm{ff}$. 
ernment of any other State follows a sense of equality among the members of the society of nations. ${ }^{166}$ As Vattel wrote, "whatever privileges any one of them derives from freedom and sovereignty, [the main being independence] the others equally derive the same from the same source". ${ }^{167}$ This is essentially a negative form of State equality, revolving around non interference. ${ }^{168}$

From this viewpoint, Vattel moved to a more positive perspective, pertaining to the legal equality of States, irrespective of the actual power or might of a nation. ${ }^{169}$ Building upon what was written earlier about the society of individuals living in nature, ${ }^{170}$ he explained the proposition as follows:

Since men are naturally equal, and a perfect equality prevails in their rights and obligations, as equally proceeding from nature - Nations composed of men, and considered as so many free persons living together in a State of nature, are naturally equal, and inherit from nature the same obligations and rights. Power or weakness does not in this respect produce any difference. A dwarf is as much a man as a giant; a small republic is no less a sovereign State than the most powerful kingdom. ${ }^{171}$

Equality of States thus means that "whatever is lawful for one nation is equally lawful for any other; and whatever is unjustifiable in the one is equally so in the other". ${ }^{172} \mathrm{In}$ large part from State independence, ${ }^{173}$ therefore, "the effect of the whole is, to produce,

${ }^{166}$ See A. Mallarmé, supra, note 19, at p. 507; and, P.P. Remec, supra, note 58, at pp. 145-146.

167 Law of Nations, at p. 149. See also Droit des Gens, Vol. 1, at p. 285.

168 See D.G. Lang, supra, note 106, at p. 19.

${ }^{169}$ See C.G. Fenwick, “The Authority of Vattel”, Part II (1914), 8 American Pol. Sc. Rev. 375, at p. 378.

${ }^{170}$ See Law of Nations, at pp. lviii-lx; and also Droit des Gens, Vol. 1, at pp. 5-7.

${ }^{171}$ Law of Nations, at p. 1xii [emphasis added]. See also Droit des Gens, Vol. 1, at p. 11.

172 Law of Nations, at p. 1xii. See also Droit des Gens, Vol. 1, at p. 11.

173 See R.W. Tucker, The Inequality of Nations (New York: Basic Books, 1977), at p. 13, who wrote the following about the traditional system of State equality, such as at the time of Vattel: "The equality of States thus consisted primarily of the recognition by others of an equal claim to the right of self-help and, above all, the right to wage war. And since this right has always been the hallmark of a State's independence, it has never been easy to distinguish between the equality and the independence of States. States were equal insofar as they were independent."As well, see generally P.H. Kooijmans, The Doctrine of the Legal Equality of States: An Inquiry into the Foundations of International Law (Leyden: Sythoff, 1964).

Interestingly, see also B. Kingsbury, "Sovereignty and Inequality” (1998), 9 European J. Int'1 L. 599, at p. 599, who wrote: "Inequality is one of the major subjects of modern social and political inquiry, but it has received minimal consideration as a theoretical topic in the recent literature of international law. While the reluctance formally to confront inequality has many 
at least externally and in the eyes of mankind, a perfect equality of rights between nations, in the administration of their affairs and the pursuit of their pretensions, without regard to the intrinsic justice of their conduct'. ${ }^{174}$ This principle, wrote Vattel, is not affected by rank and precedence - quite important then ${ }^{175}$ - which are mere political issues irrelevant to the legal equality of States. ${ }^{176}$

\subsubsection{Vattel's law of nations}

It is with his law of nations that Vattel completed the externalization of "sovereignty" in Droit des Gens. This brings back the stated object of the treatise, which is to lay down the principles of the law of nations "[t]o establish on a solid foundation the obligations and rights of nations". ${ }^{177}$ In the preface, Vattel had acknowledged Hobbes as the first, to his knowledge, "who gave a distinct, though imperfect idea, of the law of nations". ${ }^{178}$ For his part, Vattel wrote the following about it: "The Law of Nations is the science which teaches the rights subsisting between nations or States, and the obligations correspondent to those rights." 179

The first thing to point out is that, because the fictitious moral person of the State has absorbed the individuals of society and represents them on the international plane, the legal normative scheme governing the relations involving such foreign elements is only concerned with the members of the society of nations, namely, the nations (or States). ${ }^{180}$ Here is how it would work: "The law of nations is the law of sovereigns; free and independent States are moral persons, whose rights and obligations we are to establish in this treatise". ${ }^{181}$ Thus the law of nations is a law which applies to nations, to

causes, it has been made possible - and encouraged - by the centrality of sovereignty as a normative foundation of international law" [footnotes omitted].

${ }^{174}$ Law of Nations, at p. Ixiii [emphasis added]. See also Droit des Gens, Vol. 1, at p. 11.

175 See G. Butler and S. Maccoby, supra, note 140, at p. 88 ff.; and, F.S. Ruddy, supra, note 109, at p. 181, who wrote: "Vattel's attention to points of diplomatic precedence may seem a bit incongruous today, but it was de rigueur in the diplomacy of the eighteenth century" [emphasis in original].

176 See Law of Nations, at p. 149: "However, as a powerful and extensive State is much more considerable in universal society than a small State, it is reasonable that the latter should yield to the former on occasions where one must necessarily hield to the other, as, in an assembly, - and should pay it those mere ceremonial deferences $[\mathrm{sic}]$ which do not, in fact, destroy their equality, and only show a superiority of order, a first place among equals." See also Droit des Gens, Vol. 1 , at p. 286.

177 Law of Nations, at p. lv [emphasis in original]. See also Droit des Gens, Vol. 1, at p. 1.

178 Law of Nations, at p. ix. See also Droit des Gens, Vol. 1, at p. x.

179 Law of Nations, at p. lv [emphasis in original]. See also Droit des Gens, Vol. 1, at p. 1.

${ }^{180}$ See P.P. Remec, supra, note 58, at p. 181, who wrote: "In its external relations, by the same reason, the state absorbs the individual men comprising it."

181 Law of Nations, at p. 3. See also Droit des Gens, Vol. 1, at p. 21. 
their mutual external relations, and to them only. ${ }^{182}$ This is something that was already coming out clearly from the full title of Vattel's work - The Law of Nations; or, Principles of the Law of Nature, applied to the Conduct and Affairs of Nations and Sovereigns. ${ }^{183}$ In fact, as one author put it, "Vattel's main achievement was in outlining the sovereign State as the subject of the law of nations", ${ }^{184}$ indeed, "the sole subjects of the law of nations". 185

For the present purposes, however, there is a more important achievement from the way Vattel used "sovereignty" that must be highlighted, namely, to set out a law of nations which would not submit them to any higher legal regime. ${ }^{186}$ This falls within the new reality, represented by the word "sovereignty", pertaining to the exclusivity of power without, and works along with the other elements already identified - (i) the moral person of the State as sole representative of the people externally, and (ii) the independence of States which entails that no nation can interfere with the internal government of another. In effect, the premise of Vattel's law of nations is "sovereignty" as "independence", meaning not only that States are not submitted to any external authority, but also that States are not submitted to any higher law externally.

It is with respect to his system of international law that Vattel borrowed most from Christian Wolff, ${ }^{187}$ something he himself humbly admitted in the preface ${ }^{188}$ - "Those who have read Monsieur Wolf's treatises on the law of nature and the law of nations,

182 See P.P. Remec, supra, note 58, at p. 128: "Vattel's aim was to establish a definite body of laws which regulate the relations among States, laws which would subsume these relations in their entirety and yet exclude analogous relations among subjects other than States. For this purpose he constructed a very elaborate system of several kinds of the law of nations" [footnotes omitted].

${ }^{183}$ This is Joseph Chitty's translation. The original title, in French, reads: Le Droit des Gens; ou Principes de la loi naturelle appliqués à la conduite \& aux affaires des Nations \& des Souverains.

184 P.P. Remec, supra, note 58, at p. 180 [emphasis in original].

185 Id., at p. 190.

${ }^{186}$ See M. Koskenniemi, From Apology to Utopia - The Structure of InternationalLegal Argument (Helsinki: Lakimiesliiton Kustannus, 1989), at p. 94, who expressed the following opinion: "Vattel distinguishes himself from early lawyers precisely by denying the enforceability of theories of justice."

187 See, generally, L. Olive, "Wolff", in A. Pillet (ed.), Les fondateurs du droit international (Paris: Giard and Brière, 1904), 447; and, A. Renaut, "Wolff Christian, 1679-1754 - Principes du droit de la nature et des gens, 1758", in F. Chatelet, O. Duhamel and E. Pisier (eds.), Dictionnaire des Oeuvres Politiques (Paris: Presses universitaires de France, 1986), 879.

188 It is commonly know that Vattel considerably borrowed ideas and materials, but also the order and arrangement of his work; see E. Jouannet, supra, note 18, at p. 28. H. Wheaton, supra, note 54, at p. 185, provided a table comparing Droit des Gens and Wolff's Law of Nations, chapter by chapter. 
will see what advantage I have made of them". ${ }^{189}$ Thus following Wolff, Vattel articulated the law of nations as both natural law and positive law. ${ }^{190}$ As regards the law of nature, it is applicable to nations just like it is applicable to human beings; ${ }^{191}$ this is because, like them, "[ $n]$ ations, or sovereign States, are to be considered as so many free persons living together in the State of nature". ${ }^{192}$ Accordingly, the natural law of nation is the just and reasonable application of the law of nature to the juristic person of the State; Vattel also called it the "necessary law of nation" - "Necessary because nations are absolutely bound to observe it".

This necessary law of nation is be opposed to the "positive law of nation", comprising the voluntary, the conventional and the customary laws of nations, ${ }^{193}$ which "all proceed from the will of Nations; the Voluntary from their presumed consent, the Conventional from an express consent, and the Customary from tacit consent" ${ }^{194}$ Although Vattel put all three in the same category, the voluntary law of nation is different than the other two (treaties and customs), which are truly will-based law of nations, what he referred to as "arbitrary". ${ }^{195}$ In fact, Droit des Gens deals very little with conventional and customary law of nations, and concentrates almost exclusively on necessary and voluntary law of nations. ${ }^{196}$

The voluntary law of nations, for its part, is essentially based on natural law, like the necessary law of nations - "The necessary and the voluntary laws of nations are therefore both established by nature, but each in a different manner: the former, as a sacred law which nations and sovereigns are bound to respect and follow in all their actions;

189 Law of Nations, at p. xii. See also Droit des Gens, at p. xvi.

190 See E.D. Dickinson, "Changing Concepts and the Doctrine of Incorporation" (1932), 26 American J. Int'1 L. 239, at p. 249. See also P. Guggenheim, supra, note 18, at pp. 6-7.

${ }^{191}$ See Law of Nations, at p. lvi: "As men are subject to the laws of nature, - and as their union in civil society cannot have exempted them from the obligation to observe those laws, since by that union they do not cease to be men, - the entire nation, whose common will is but the result of the united wills of the citizens, remains subject to the laws of nature, and is boud to respect them in all her proceedings" [emphasis in original]. See also Droit des Gens, Vol. 1, at pp. 2-3.

For a critical appraisal of this individual-State analogy in Vattel's international law theory, see P.P. Remec, supra, note 58, at pp. 128-129 and $183 \mathrm{ff}$.

${ }^{192}$ Law of Nations, at p. lv [emphasis in original]. See also Droit des Gens, Vol. 1, at p. 2.

193 See H. Wheaton, supra, note 54, at pp. 188-189; and, A. de Lapradelle, supra, note 22, at p. xix.

${ }^{194}$ Law of Nations, at p. lxvi [emphasis in original]. See also Droit des Gens, Vol. 1, at p. 15.

195 See Law of Nations, at p. 1xvi: "They [treaties and customs] form that species of law of nations which authors have distinguished by the name of Arbitrary" [emphasis in original]. See also Droit des Gens, Vol. 1, at p. 15. As well, see Law of Nations, at p. xv; and also Droit des Gens, Vol. 1, at pp. xxi-xxii.

${ }^{196}$ See F.S. Ruddy, supra, note 109, at p. 76. 
the latter, as a rule which the general welfare and safety oblige them to admit in their transactions with each other". ${ }^{197}$ However, this type of natural law would be different because of the subjects it regulates. ${ }^{198}$ Thus Vattel "draw a distinction between the strict application of the natural law and modifications and exceptions to it when applied to nations". ${ }^{199}$ Put another way, the voluntary law of nations would adjust natural law (i.e. the necessary law of nations) in order to correspond to the particular needs of regulating relations between States. ${ }^{200}$

So far, Vattel had followed Wolff with respect to the categorization of the different type of laws of nations, ${ }^{201}$ but he then distanced himself from his master when he repudiated the latter's derivation of the voluntary law of nation. ${ }^{202}$ Indeed, Wolff had put forward the idea of a civitas maxima, that is, an overarching authority instituted by nature itself of which all nations of the world would be members; ${ }^{203}$ it is that universal civil society which is deemed to have accepted the voluntary law of nations and would thus legitimize it. ${ }^{204}$ Vattel rejected it in the clearest terms ${ }^{205}$ - "This idea does not satisfy me; nor do I think the fiction of such a republic either admissible in itself, or capable of affording sufficiently solid grounds on which to build the rules of the universal law of nations, which shall necessarily claim the obedient acquiescence of sovereign States". ${ }^{206}$

In view of his theory of the independence of States, which is represented in the word "sovereignty" used in Droit des Gens, Vattel could not accept the contention that

\section{Law of Nations, at p. xv. See also Droit des Gens, Vol. 1, at p. xxi.}

${ }^{198}$ See Law of Nation, at p. vii: "The application of a rule to various subjects, can no otherwise be made than in a manner agreeable to the nature of each subject." See also Droit des Gens, Vol. 1, at p. vi. As well, see Law of Nations, at p. 1x; and also Droit des Gens, Vol. 1, at pp. 7-8.

199 F.S. Ruddy, supra, note 109, at p. 75.

${ }^{200}$ See M. Koskenniemi, supra, note 186, at p. 90. See also C.G. Fenwick, supra, note 142, at p. 401; P.P. Remec, supra, note 58, at pp. 140-141; and, C. Phillipson, supra, note 28, at p. 492: "The laws that apply to nations differ from those that apply to men, since a nation is a different type of moral being from a man."

${ }^{201}$ For a comparison of Wolff's scheme of law of nations with Vattel's, see F.S. Ruddy, supra, note 109 , at pp. 100-110.

${ }^{202}$ See O. Nippold, "Introduction", in J.B. Scott (ed.), The Classics of InternationalLaw - Wolff, Vol. 2 (Oxford: Clarendon Press, 1934), xi , at p. xlvi. See also J. Westlake, supra, note 28, at p. 72; C. Phillipson, supra, note 28, at pp. 493-494; and, F.S. Ruddy, id., at pp. 98-100.

203 See Wolff's Law of Nations, at pp. 16-17; and also Ius Gentium, at p. 7.

204 See Wolff's Law of Nations, at pp. 17-18; and also Ius Gentium, at p. 8.

${ }^{205}$ See H. Wheaton, supra, note 54, at p. 186; A. Mallarmé, supra, note 19, at pp. 503-504; A. de Lapradelle, supra, note 22, at p. xxv; G. Gidel, supra, note 159, at p. 581; E.D. Dickinson, supra, note 190, at p. 249; and, D.G. Lang, supra, note 106, at p. 17.

206 Law of Nations, at p. xiii. See also Droit des Gens, Vol. 1, at p. xvii. 
there was an authority above the nation. ${ }^{207}$ Indeed, not only is there no need for a great commonwealth to provide order among States - unlike private individuals, who need a public authority to rule them ${ }^{208}$ - but more importantly, "that independence is even necessary to each State, in order to enable her properly to discharge the duties she owes to herself and to her citizens, and to govern herself in the manner best suite to her circumstances". ${ }^{209}$ The exclusivity of power held by this moral person representing the individuals in society is thus fundamentally not conciliable with the notion of civitas maxima. ${ }^{210}$

Instead of this supra-civil society, ${ }^{211}$ therefore, Vattel suggested that there existed a society of nations, similar to the society of human beings in the State of nature, among which there is an agreement to accept the voluntary law of nations as a rule of law to regulate their relations. ${ }^{212}$ It is sufficient, he wrote, "that nations should conform to

207 See P.P. Remec, supra, note 58, at p. 190; and, F.S. Ruddy, supra, note 109, at p. 71: "Instead of a civitas maxima Vattel acknowledged that each State was independentof every other State, to be regarded as a free individual living in a State of nature, and recognizing no laws other than nature's and God's." See also E. Jouannet, supra, note 18, at p. 156: "L'identification par Vattel du droit des gens positif au seul droit externe et coercible s'imposant aux Etats ne peut dès lors s'expliquer par le fondement volontariste des droits et obligations qu'il comporte puisque ce fondement est en réalité hétérogène, à la fois volontaire et naturel. Elle résulte de la consistance et la finalité des obligations, c'est-à-dire du fait que ces obligations soient instituées dans le respect maximum de la liberté et l'indépendance des Etats."

${ }^{208}$ Indeed, Vattel wrote: "States conduct themselves in a different manner from individuals. It is not usually the caprice or blind impetuosity of a single person that forms the resolutions and determines the measures of the public: they are carried on with more deliberation and circumspection: and, on difficult or important occasions, arrangements are made and regulations established by means of treaties"; Law of Nations, at p. xiv. See also Droit des Gens, Vol. 1, at p. xix. ${ }^{209}$ Law of Nations, at p. xiv. See also Droit des Gens, Vol. 1, at p. xix.

${ }^{210}$ See H. Muir Watt, "Droit naturel et souveraineté de l'Etat dans la doctrine de Vattel" (1987), 32 Archives Philo. D. 71, at p. 77, who wrote: "En somme, pour Vattel, si l'Etat se trouve, comme l'homme à l'origine, dans l'état de nature, la souveraineté de l'Etat s'oppose toutefois à toute aliénation de sa liberté, et empêche donc d'instituerune société civile semblable à celle qui existe entre les hommes."

211 See the following critique by A. Mallarmé, supra, note 19, at p. 591: "On doit donc le louer d'avoir repoussél'idée d'une Civitas maxima. Mais sa doctrine ne fournit malheureusementrien de plus satisfaisant à la place." See also C. Phillipson, supra, note 28, at p. 494.

${ }^{212}$ See F.S. Ruddy, supra, note 109, at p. 93. However, see the following remarks by P.P. Remec, supra, note 58, at p. 146: "Vattel was of course aware that there is no actual proof for such an agreement among nations. But since the very existence of the society of mankind postulates such an agreement, Vattel maintains that this consent must be presumed as given voluntarily. The law created through such presumed consent he names the 'voluntary Law of Nation', thus adopting the terminology of his teacher Wolff' [footnotes omitted]. 
what is required of them by the natural and general society established between all mankind". ${ }^{213}$ Furthermore, instead of deducing the legitimacy of these rules from the fiction of a great commonwealth above States, ${ }^{214}$ he suggested that the voluntary law of nations is "deducible from the natural liberty of nations, from the attention due to their common safety, from the nature of their mutual correspondence, their reciprocal duties, and the distinctions of their various rights, internal and external, perfect and imperfect". ${ }^{215}$

Therefore, in attempting to explain the basis of the voluntary law of nations, Vattel replaced a fiction by another, that is, he relied on the fiction of a presumed consent among the members of the society of nations instead of relying upon the fiction of the civitas maxima.$^{216}$ It also appears that, to further support his reasoning, Vattel reverted back to following Wolff ${ }^{217}$ - in fact, took over the distinctions introduced by their common mentor, Leibnitz ${ }^{218}$ - and referred to rights and obligations of States as being "internal and external, perfect and imperfect". ${ }^{219}$ Here is how Vattel elaborates his system:

In order perfectly to understand this, it is necessary to observe, that the obligation, and the right which corresponds to or is derived from it, are distinguished into external and internal. The obligation is internal, as it binds the conscience, and is deduced from the rules of our duty: it is external, as it is considered relatively to other men, and produces some right between them. The internal obligation is always the same in its nature, though it varies in degree; but the external obligation is divided into perfect and imperfect; and the right that results from it is also perfect or imperfect. The perfect right is that which is accompanied by the right of compelling those who refuse to fulfil the correspondent obligation; the imperfect right is

${ }^{213}$ Law of Nations, at p. xiv. See also Droit des Gens, Vol. 1, at p. xix.

${ }^{214}$ Interestingly, see P. Guggenheim, supra, note 18, at pp. 8-9, who downplay the importance of Vattel different source of voluntary law of nations: "Pourtant, la civitas maxima de Wolff, tout comme la société des nations de Vattel, a seulement le sens d'une norme fondamentale formelle, d'une règle de création de droit, d'une base de validité de l'ordre juridique, au même titre que la norme fondamental hypothétique de Kelsen" [footnotes omitted]. Similarly, see P.P. Remec, supra, note 58, at p. 196: "This second type of the society of nations, which even has a special 'nature', is really nothing else but a watered-down version of Wolff's civitas maxima."

${ }^{215}$ Law of Nations, at p. xiv. See also Droit des Gens, Vol. 1, at p. xx.

${ }^{216}$ See P.P. Remec, supra, note 58, at pp. 135-136; and, E. Jouannet, supra, note 18, at pp. 100103.

217 See Law of Nations, at p. xiv; and also Droit des Gens, Vol. 1, at p. xx. For a comparison of the two on this issue, see F.S. Ruddy, supra, note 109, at pp. 102-103. See also E. Jouannet, id., at pp. 211-216.

218 See A. de Lapradelle, supra, note 22, at p. xvi.

${ }^{219}$ Law of Nations, at p. xiv. See also Droit des Gens, Vol. 1, at p. xx. 
unaccompanied by that right of compulsion. The perfect obligation is that which gives to the opposite party the right of compulsion; the imperfect gives him only a right to ssk. $^{220}$

In this scheme, each State obligation implies a corresponding State right, which are either "internal", when located in the same person, or "external", when located in different persons. ${ }^{21}$ Although both are real, there is no right to force an internal obligation, which is only imposed "on the conscience of each". ${ }^{222}$ And, this "line of distinction between the internal and external right", according to Vattel, amounts to that "between the necessary and the voluntary law of nations". ${ }^{223}$ Further, only part of this voluntary law is enforceable because such external rights are either "perfect" or "imperfect",224 corresponding to a right to compel or a right to request, respectively. ${ }^{225}$ It is through a contract (that is, a treaty), that an imperfect right can be made perfect. ${ }^{226}$ With a treaty, Vattel wrote, "we acquire a perfect right to things to which we before had only an imperfect right, so that we may thenceforward demand as our due what before we could only request as an office of humanity". ${ }^{227}$

In the absence of such perfected right, the principle of State independence requires that no nation can enforce on the international plane rules based on the voluntary law of nations. ${ }^{228}$ Vattel explicated thus:

${ }^{220}$ Law of Nations, at p. 1xii [emphasis in original]. See also Droit des Gens, Vol. 1, at p. 10.

${ }^{221}$ See L. Ehrlich, “The Development of InternationalLaw as a Science” (1962), 105 R.C.A.D.I. 173, at p. 236. See also P.P. Remec, supra, note 58, at pp. 136-137; and, M. Koskenniemi, supra, note 186 , at p. 92 .

${ }^{222}$ Law of Nations, at p. xiv. See also Droit des Gens, Vol. 1, at p. xx.

223 Law of Nations, at p. xv. See also Droit des Gens, Vol. 1, at p. xx.

${ }^{224}$ Examples of matters where State rights are a priori imperfect include commerce, safe passage, acquisition of territory, dispute settlement, embassy. For more on these illustrations, see F.S. Ruddy, supra, note 109, at p. $111 \mathrm{ff}$.

${ }^{225}$ See A. Mallarmé, supra, note 19, at p. 540; C.G. Fenwick, supra, note 142, at pp. 402-403; E.D. Dickinson, supra, note 190, at p. 249; F.S. Ruddy, id., at p. 88; D.G. Lang, supra, note 106, at p. 26; and, E. Jouannet, supra, note 18, at pp. 151-153.

${ }^{226}$ See A. de Lapradelle, supra, note 22, at p. xviii, who wrote: "Où le droit est parfait, les traités sont inutiles. [...] Où le droit est imparfait, au contraire, les traités lui donnent la perfection, qui lui manque." See also P.P. Remec, supra, note 58, at p. 197.

${ }^{227}$ Law of Nations, at p. 197. See also Droit des Gens, Vol. 1, at p. 377.

${ }^{228}$ See Law of Nations, at p. xviii: "Nations being free and independent, though the conduct of one of them be illegal and condemnable by the laws of conscience, the others are bound to acquiesce in it, when it does not infringe upon their perfect rights. The liberty of that nation would not remain entire, if the others were to arrogate to themselves the right of inspecting and regulating her actions; an assumption on their part, that would be contrary to the law of nature, 
It is now easy to conceive why the right is always imperfect, when the correspondent obligation depends on the judgment of the party in whose breast it exists; for if, in such a case, we had a right to compel him, he would no longer enjoy the freedom of determination respecting the conduct he is to pursue in order to obey the dictates of his own conscience. Our obligation is always imperfect with respect to other people, while we possess the liberty of judging how we are to act: and we retain that liberty on all occasions where we ought to be free. ${ }^{229}$

Accordingly, the breach of a rule of voluntary law of nations, which is thus external and not perfected by treaty, will go unsanctioned at the international level. ${ }^{230}$ Vattel even wrote that "nations should suffer certain thing to be done, though in their own nature unjust and condemnable, because they cannot oppose them by open force, without violating the liberty of some particular State, and destroying the foundations of their natural society". ${ }^{231}$ And all of this is essentially linked to the exclusivity of power without and to State independence..$^{232}$

\subsection{Recapitulation}

Fundamentally, therefore, the legal system put forward by Vattel to regulate the relations between independent States constitutes the last element in order to accomplish the externalization of authority through the use of "sovereignty" in Droit des Gens. Indeed, this word now pertains to the exclusivity of power without. That is to say, it represents the reality of the authority to govern vested in a political body which is the sole representative of individuals in society, not only for domestic affairs, but also for matters involving foreign nations. Also, with the association of "sovereignty" and "independence", Vattel further changed the reality in two ways: (i) by having nations enjoy exclusive power to rule, not only among other internal authorities within, but among other public authorities without, based on the principle of non-intervention;

which declares every nation free and independent of all the others" [emphasis in original]. See also Droit des Gens, Vol. 1, at p. 5.

${ }^{229}$ Law of Nations, at p. 1xii [emphasis added]. See also Droit des Gens, Vol. 1, at p. 10.

${ }^{230}$ See P. Guggenheim, supra, note 18, at p. 18: "Bien que les nations ne puissentrien y changer et que les coutumes et traités qui sont contraires au droit des gens interne, soient 'illégitime', ils seront valables dans le cadre du droit externe. C'est particulièrement le cas si ce dernier est 'parfait', c'est-à-dire s'il produit le droit de contraite" [footnotes omitted].

${ }^{231}$ Law of Nations, at p. 1xiii. See also Droit des Gens, Vol. 1, at p. 12.

${ }^{232}$ See F.S. Ruddy, supra, note 109, at p. 81: "The implications from the freedom and independence of States were for Vattel, the basis of this Voluntary Law of Nations. There was between nations an ethical and legal relationship, and ideally both should correspond. Where they did not correspond, the spirit of the law (the Necessary Law of Nations) had to yield to the letter of the law as it were, the implications from the freedom and independence of states, the Voluntary Law of Nations. Perfect rights were the dividing line between the two." 
and (ii) by having a legal scheme which regulates the relations of these moral persons that does not submit them to any higher political or legal authority, based on the socalled voluntary law of nations.

\section{Extended historical context}

The foregoing analysis of the word "sovereignty" in Droit des Gens will now bring into play more historical context (outre Vattel's background) including the social and political situations of the 18th century, the intellectual milieu in which he wrote, and the audience targeted by his work.

"In the eighteenth century," wrote Nussbaum, "the countries of Western civilization presented, in comparison with conditions of the sixteenth and seventeenth centuries, a picture of relative stability". ${ }^{233}$ There were still numerous armed conflicts in Europe, ${ }^{234}$ but fanatic religious wars gave way to more orderly wars of limited means and objectives between rulers, which were fought by their military forces. ${ }^{235}$ As Robson explained:

They were a natural revulsion from the horrors of the Thirty Years War, where fanaticism and moral indignation had multiplied the number of atrocities. Though there were great wars, devastation and unnecessary bloodshed were kept in check by strict adherence to the rules, customs, and laws, of war, the accepted code of the eighteenth-century war-game..$^{236}$

${ }^{33}$ A. Nussbaum, supra, note 111, at p. 126. See also A. Watson, The Evolution of International Society - A Comparative Historical Analysis (London and New York: Routledge, 1992), at p. 212, who wrote: "The eighteenth century European grande république stands out amongst States systems and phases of systems as exceptionally successful. It was well managed by the conscious co-operation, or at least restraint, of its member sovereigns, who valued their independence within a non-hegemonial framework of balanced order."

${ }^{234}$ See Q. Wright, A Study of War (Chicago: University of Chicago Press, 1964), at p. 644, where in Table 35, he listed 18 active armed conflicts in Europe between 1700 and 1750 - France was involved in four of them, Great Britain in eight, the Netherlands in five, Spain in seven, Austria in seven, Prussia in four, Savoy (Sardinia) in five, Poland in three, Russia in seven, and Sweden in five. See also F. of Alamein, A History of Warfare (London: Collins, 1968), at p. $315 \mathrm{ff}$.

235 See F.S. Ruddy, supra, note 109, at pp. 254-255, who wrote: "War had ceased to be an instrument for enforcing morality as it was seen by Grotius, but rather it had become an accepted tool of State practice in eighteenth century Europe, for which the State's interests rather than objective notions of right and wrong were the criterion."

236 E. Robson, "The Armed Forces and the Art of War", in J.O. Lindsay (ed.), The New Cambridge Modern History, Vol. 7, The Old Regime, 1713-63 (Cambridge: Cambridge University Press, 1957), 163, at p. 165. 
Socially, therefore, this new genre of armed conflicts meant that there was less devastation and misery for the population of the affected territories, ${ }^{237}$ a situation that was going to last until the French Revolution and the nationalist wars that ensued. ${ }^{238}$

This greater restrain and "humanity" in wars, ${ }^{239}$ having a direct beneficial effect on civilians, was also the result of a change of approach to warfare, which aimed at making it more honourable and contained. ${ }^{240}$ However, this was not true of every type of battles - on the sea, it was generally possible to control naval warfare; but on the ground, it was in reality impossible to maintain discipline on all troop activities. ${ }^{241}$ As van Vollenhoven described:

Let us remember in what period [Vattel] wrote; from 1740 till 1748 the war of the Austrian Succession raged; from 1756 till 1763 the Seven Years' War. After the peace of Aix-la-Chapelle thirty thousand soldiers were shot or sent to the galleys, because of licentious misconduct and insubordination during the fight, due among other causes to their pitiable treatment. ${ }^{242}$

See A. Nussbaum, supra, note 111, at p. 126; G. Butler and S. Maccoby, supra, note 140, at p. 137; and, W. Dorn, "European Militarism”, in G.B. Turner (ed.), A History of Military Affairs since the Eighteenth Century (New York: Harcourt, Brace, 1956), 2, at p. 3: "Never, before or since, save perhaps in Renaissance Italy, was the civilian population more secure against wanton devastation, atrocities and the systematic plunder of requisition warfare." See contra, A. Sorel, Europe Under the Old Regime (New York: Harper and Row, 1947), at pp. 69-75.

${ }^{238}$ See E. Robson, supra, note 236, at p. 174: "To sum up: in the eighteenth century, wars were conducted with moderation. With the casting out of religious fanaticism, the evil of war was reduced to a minimum never approached before or since. This period of relatively civilized warfare was ended by the treatment meted out to the Loyalists by the victorious colonists at the conclusion of the War of American Independence, and then by the French Revolution wars. War, which had ceased in the seventeenth century to be a weapon of religious fanaticism, became an instrument of nationalist fanaticism."

239 Vattel himself wrote the following in Law of Nations, at p. 348: "The humanity with which most nations in Europe carry on their wars at present cannot be too much commended." See also Droit des Gens, Vol. 2, at p. 107.

240 See F.S. Ruddy, supra, note 109, at p. 249. See also A. Vagts, A History of Militarism Civilian and Military (New York: Meridian Books, 1959), at p. $41 \mathrm{ff}$.

${ }^{241}$ See M.S. Anderson, War and Society in Europe of the Old Regime, 1618-1789(New York: St. Martin's Press, 1988), at pp. 99-100: “These decades [1660-1740] saw a continuation of the process of extending more effective and detailed State control over armed forces which had been visibly in the first half of the seventeenth century. Slowly, and with very varying effect, central governmentsincreased their attention to the day-to-day running of their armies and navies, struggling to increase their effectiveness, to reduce inefficiency and waste and to enforce greater uniformity in organization, tactics and armament." See also E. Robson, supra, at pp. 163-165.

${ }^{242}$ C. van Vollenhoven, supra, note 17, at p. 34. 
Although more civilized, the wars associated with the numerous conflicts over territory and power during the 18 th century continued to cause much social concerns, property destruction and human casualties. ${ }^{243}$ Thus the issue of how to regulate the European chessboard through diplomatic and legal means was still very much the question par excellence.

It is generally acknowledged that raison d'état ${ }^{244}$ politics reached its apogee during this period ${ }^{245}$ - "Never before had the reason of State been opposed more impudently to the most elementary laws of honor and justice". ${ }^{246}$ The 18 th century author Baron von Bielfeld was of the view that this principle, whether or not explicitly, had been adopted by all rulers, whose decisions were based on his or her own interests, and now according to the new trend, were based on the interests of the State or national interests: ${ }^{247}$

Each society, each State, can and even must use all legitimate means that seem necessary either for its preservation or for the increase of its real or relative might. This rule, dictated by the law of nature as well as by politics, acts as the foundation of all operations of the different cabinets of Europe, of the system that each favours,

${ }^{243}$ See A. Nussbaum, supra, note 111, at p. 127, who succinctly explained that "the eighteenth century witnessed considerable shifts in the territory and might of the various European States. By the Peace of Nystadt (1721), Russia became a leading European power under Peter the Great. At the same time Sweden was shorn of her dominant position in the north of Europe. The loss of the Protestant side, however, was more than offset by the rise of Prussia under Frederick the Great and by England's tremendous colonial and commercial expansion. Through Russia's ascent, the relative share of the Catholic States in the total of political power was further diminished, though France still preserved her pre-eminence, now perhaps more on the basis of her culture than on the basis of her military position."

${ }^{244}$ That is, "reason of State", or essentially the "interest of the State". This concept, generally attributed to Francesco Guicciardini (1483-1540), is to the effect that the well-being of a polity justifies more or less any means to promote it internally and externally; it contrasts with stoicism, universal morality, and natural law. It has a direct lineage with earlier Machiavelism and subsequent Realpolitik. See E. Thuau, Raison d'Etat et pensée politique à l'époque de Richelieu (Paris: Colin-Presses universitaires françaises d'Athènes, 1966); W.F. Church, Richelieu and Reason of State (Princeton: Princeton University Press, 1972); G. Post, "Ratio publicae utilitatis, ratio status et 'raison d'Etat"', in C. Lazzeri and D. Reynié (eds.), Le pouvoirde la raison d'Etat (Paris: Presses universitaires de France, 1994), 13; Y.C. Zarka (ed.), Raison et déraison d'Etat Théoriciens et théories de la raison d'Etat aux XVIe et XVIIe siècles (Paris: Presses universitaires de France, 1994); and, A.P. d'Entrèves, supra, note 4, at pp. 44-49.

${ }^{245}$ See R.S. Ruddy, supra, note 109, at p. 73.

${ }^{246}$ A. Sorel, supra, note 237, at p. 17.

${ }^{247}$ See, generally, J. Ferrari, Histoire de la raison d'État (Paris: Kimé, 1992). 
of the measures that it takes, of the alliances that it strikes, of the wars that it declares, or the peace that it concludes. ${ }^{248}$

"The reason of State being the rule," Sorel further wrote, "aggrandizement became the object of statecraft." 249 Catherine the Great, who followed Peter the Great in Russia's external policies of expansion, is deemed to have once said that "He who gains nothing, loses". 250

Along with raison d'état and agrandissement, the third core political principle of 18 th century Europe was that of the balance of power, or equilibrium of power. ${ }^{251}$ This

248 J.F. Bielfeld, Institutions politiques, Vol. 2 (Leiden: Bassompierre, 1768), at pp. 38-139; [emphasis added] author's translation of: "Chaque Société, chaque Etat, peut et doit même se servir de tous les moyens légitimes qui lui paroissentnécessaires, soit à sa conservation, soit à l'augmentation de sa puissance réelle et relative. Cette règle dictée par la Loi naturelle aussi bien que par la Politique, sert de fondement de toutes les opérations des différents Cabinets de l'Europe, au système chacun d'eux embrasse, aux mesures qu'il prend, aux alliances qu'il contracte, à la guerre qu'il déclare, ou la paix qu'il conclut" [emphasis added] [spelling modernized].

${ }^{249}$ A. Sorel, supra, note 237, at p. 11. On the principle of aggrandisement in the 18th century, see M.S. Anderson, Europe in the Eighteenth Century, 1713-1783, 2nd ed. (New York: Longman, 1976), at p. 216 ff.; and, generally, G. Sfez, Les doctrines de la raison d'État (Paris: Colin, 2000).

${ }^{250}$ See A. Sorel, ibid. See also M.S. Anderson, Britain's Discovery of Russia, 1553-1815 (London: Macmillan, 1958), at p. 215 ff.; G.S. Thomson, Catherine the Great and the Expansion of Russia (Westport, U.S.: Greenwood, 1985), at p. 109 ff.; J.T. Alexander, Catherine the GreatLife and Legend (New York and Oxford: Oxford University Press, 1989), at p. 121 ff.; and, American Memory, "Imperial Expansion and Maturation: Catherine II" (1996), <lcweb2.loc.gov/ cgi-bin/query/r?frd/cstdy:@ field(DOCID+ru0021)>.

${ }^{251}$ For a history of the principle, see $\mathrm{C}$. Dupuis, Le principe d'équilibre et le concert européenDe la paix de Westphalie à l'acte d'Algésiras (Paris: Perrin, 1909). See also, generally, E. Nys, "La théorie de l'équilibre européen" (1883), 25 Rev. D. Int'l \& Légis'n Comp. 34; A. Vagts, "The Balance of Power: Growth of an Idea" (1948), 1 World Politics 82; H. Butterfield, "The Balance of Power", in H. Butterfield and M. Wight (eds.), Diplomatic Investigations - Essays in the Theory of International Politics (London: Allen and Unwin, 1966), 132; M. Wight, "The Balance of Power", in H. Butterfield and M. Wight (eds.), Diplomatic Investigations - Essays in the Theory of International Politics (London: Allen and Unwin, 1966), 149; M. Beloff, The Balance of Power (Montreal: McGill University Press, 1967); M. Wight (ed.), Theory and Practice of the Balance of Power, 1486-1914 (London: Dent, 1975); and, M. Sheehan, Balance of Power - History and Theory (London and New York: Routledge, 1996).

It is in the middle of the 18th century that David Hume dwelled upon the idea of balance of power in political theory; see D. Hume, "Of the Balance of Power", in K. Haakonssen (ed.) David Hume - Political Essays (Cambridge: Cambridge University Press, 1994), 154, first published in 1752. 
is what Vattel had to say about it: ${ }^{252}$

The continual attention of sovereigns to every occurrence, the constant residence of ministers, and the perpetual negotiations, make of modern Europe a kind of republic, of which the members - each independent, but all linked together by the ties of common interest - unite for the maintenance of order and liberty. Hence arose that famous scheme of the political balance, or the equilibrium of power; by which is understood such a disposition of things, as that no one potentate be able absolutely to predominate, and prescribe laws to the others. ${ }^{253}$

Already at the beginning of the century, ${ }^{254}$ the principle of the balance of power was officially enshrined in the documents of the Peace of Utrecht in 1713, which ended the War of the Spanish Succession. ${ }^{255}$ Indeed, the Anglo-Spanish Treaty, ${ }^{256}$ at Article II, stated that one of its objective was "to settle and establish the peace and tranquillity of

${ }^{252}$ On Vattel and the principle of balance of power, see E.V. Gulick, Europe's Classical Balance of Power-A Case History of the Theory and Practice of One of the Great Concepts of European Statecraft (Ithaca, U.S.: Cornell University Press, 1955), at pp. 59-62.

${ }^{253}$ Law of Nations, at p. 311 [emphasis added]. See also Droit des Gens, Vol. 2, at pp. 39-40.

${ }^{254}$ See G. Zeller, "Le principe d'équilibre dans la politique international avant 1789" (1956), 215 Rev. Historique 25, at p. 34; and, M.S. Anderson, "Eighteenth-Century Theories of the Balance of Power", in R. Hatton and M.S. Anderson (eds.), Studies in Diplomatic History Essays in memory of David Bayne Horn (Hamden: Archon Books, 1970), 183, at p. 184. See also A. Nussbaum, supra, note 111, at p. 127, who wrote: "Its [the balance of power principle] incorporation in the Peace of Utrecht simply amounts to a commendatory official comment and, perhaps, to an interpretative rule applicable to this particular treaty."

It is worth pointing out also that the principle of the balance of power has had a continuing relevance in the 20th century period of international law. Indeed, as L.F.L. Oppenheim, supra, note 16, at p. 73, wrote: "The first and principal moral is that a Law of Nations can exist only if there be an equilibrium, a balance of power, between the members of the Family of Nations"; see also, in the context of the League of Nations, the same opinion expressed,L.F.L. Oppenheim, The League of Nations and Its Problems - Three Lectures (London: Longmans, Green, 1919), at p. 21. As well, see the contemporary account given by B. Kingsbury, "Legal Positivism as Normative Politics: International Society, Balance of Power and Lassa Oppenheim's Positive International Law" (2002), 13 European J. Int'1 L. 401.

${ }^{255}$ See T. Twiss, The Law of Nations Considered as Independent Political Communities, Vol. 1 (Oxford: Oxford University Press, 1861), at pp. 152-155; and, R. Redslob, Histoire des grands principes du droit des gens - Depuis l'antiquité jusqu'à la veille de la grande guerre (Paris: Rousseau, 1923), at pp. 252-253.

${ }^{256}$ For the full text of the Anglo-Spanish Treaty, signed at Utrecht on July 1713, in both their Latin and English versions, see C. Parry (ed.) Consolidated Treaty Series, Vol. 28 (Dobbs Ferry, U.S.: Oceana Publications, 1969), 295. It is the English translation that will be used here, which Parry said is taken from Jenkinson, Treaties, Vol. II, 66. 
Christendom, by an equal balance of power (which is the best and most solid foundation of mutual friendship and of a concord which will be lasting on all sides)" ${ }^{257}$

These three principles (raison d'état, aggrandisement, and balance of power) helped to maintain and nurture, during that period, a system of politically independent, yet culturally related, societies in Europe. ${ }^{258}$ On this dichotomy autonomy versus interconnection, Pieter Geyl wrote: "Each might feel warmly for his own country and at moments of international tension side with it unhesitatingly, yet each knew that Europe constituted a cultural unity" ${ }^{259}$ Along with this growing commonality of culture, there was also an increasing homogeneity of thoughts among the intellectuals of the 18th century. Norman Hampson appositely observed:

Some of the most eminent writers of the age, Montesquieu, Voltaire, Hume and, later in the century, Gibbon, set themselves to produce history of a new kind, which would illustrate, in terms of human society, the kind of complex interdependence that biologists were discovering in the animal world. Montesquieu's tout est extrêmement lié summarized the attitude of an age. ${ }^{260}$

It is indeed during this period that many began to theoretically view Europe globally, that is, in terms of all the peoples and all the countries, instead of on the basis of a single nation. ${ }^{261}$

At the turn of the 18th century, ${ }^{262}$ some intellectuals even put forward the idea of a

${ }^{257}$ Id., at pp. 325-326 [emphasis added].

${ }^{258}$ See F.H. Hinsley, Power and the Pursuit of Peace: Theory and Practice in the History of Relations between States (Cambridge: Cambridge University Press, 1963), at p. 163, who wrote: "Despite the references to the fact that they were culturally one and politically interrelated, the main emphasis now, in contrast to earlier thinking, is that, though culturally and politically interrelated, the European States were also politically several. And this was the conception of Europe that prevailed after the middle of the eighteenth century, among those who criticized the international system no less than among those who accepted it."

${ }^{259}$ P. Geyl, Encounters in History (Clevaland, U.S. and New York: World Publishing, 1961), at p. 301. See also G. Barraclough, History in a Changing World (Oxford: Blackwell, 1955), at p. 169 , who speak of the Europe of the middle of the 18th century as a "unity in plurality" and a "unity in diversity".

${ }^{260}$ N. Hampson, The Enlightenment (Harmondsworth, U.K.: Penguin Books, 1968), at pp. 108109.

${ }^{261}$ P. Hazard, European Thought in the Eighteenth Century (London: Hollis and Carter, 1954), at pp. 437-438.

${ }^{262}$ It is interesting to note that, at the turn of the next century, this idea was still very much alive with the work of Immanuel Kant, Zum ewigen Frieden (Leipzig: Schubert, 1838), first published in 1795; see the English version, I. Kant, Perpetual Peace (New York: Columbia University Press, 1939). See also T. Ruyssen, Les sources doctrinalesde l'internationalisme, Vol. 3, De la Révolution française au milieu du XIXe siècle (Paris: Presses universitaires de France, 1961), at p. 148 ff. 
world federation, that is, of a European federation ${ }^{263}$ - William Penn, Essay towards the Present and Future Peace of Europe by the Establishment of an European Dyet, Parliament or Estates, ${ }^{264}$ published in 1693, John Bellers, Some Reasons for an European State, ${ }^{265}$ published in 1710, and Charles Irénée Castel Abbé de Saint-Pierre, Mémoires pour rendre la Paix perpétuelle en Europe, published in $1712 .{ }^{266}$ However, although the lumières agreed that Europe was "a kind of great republic", ${ }^{267}$ many of them (including Voltaire, Rousseau, and Montesquieu) opined that an actual federation was a utopian aspiration" ${ }^{268}$ - "But the almost universal reaction of the eighteenth century was the criticism that [Abbé de Saint-Pierre and others] had neglected the realities of the modern States' system". ${ }^{269}$

${ }^{263}$ See C.L. Lange, "Histoire de la doctrine pacifique et de son influence sur le développement du droit international” (1926), 13 R.C.A.D.I. 171, at pp. 302-315; A. Nussbaum, supra, note 111, at pp. 140-142; and, F.H. Hinsley, supra, note 258, at pp. 33-45.

${ }^{264}$ W. Penn, Essay Towards the Prefent and Future Peace of Europe by the Eftablifhment of an European Dyet, Parliament or Eftates (London: n.b., 1693).

265 J. Bellers, Some Reasons for an European State: Proposed to the Powers of Europe, by an Universal Guarantee and an Annual Congress, Senate, Dyet, or Parliament to settle any disputes about the bounds and rights of Princes and States hereafter: With an abstract of a Scheme form'd by King Henry the Fourth of France upon the same subject. And also a proposalfor a General Council or Convocation of all the different religious persuasions in Christendom (not to dispute what they differ about, but) to settle the General Principles they agree in, by which it will appear that they may be good subjects and neighbours, though of differentapprehensionsof the way to Heaven: In order to prevent broils and wars at home, when foreign wars are ended (London: n.b., 1710).

${ }^{266}$ C.I.C. de Saint-Pierre, Mémoires pour rendre la paix perpétuelle en Europe (Cologne: Jacques le Pacifique, 1712). This work was later reprinted in two volumes under the name of Projet pour rendre la Paix perpétuelle en Europe (Utrecht: Antoine Schouten, 1713).

${ }^{267}$ See P. Hazard, supra, note 241, at p. 437, who referred to Voltaire as saying that Europe was "a kind of great republic, embracing several States, some monarchical, some not, the former aristocratic, the others democratic, but all in relationship one with another, all having one and the same religious basis, the same principles public law, the same political ideas, all of them unknown in the other parts of the world" [emphasis added].

${ }^{268}$ See J. Hodé, L'idée de fédération internationaldans l'histoire-Les précurseurs de la Société des Nations (Paris: Éditions de la vie universitaire, 1921), at pp. 136-137. See also Voltaire, "Au Roi de Prusse [Paris, 15 May 1742]", in T. Besterman (ed.), Voltaire-Correspondance, Vol. 2, 1739-1748 (Paris: Gallimard, 1965), 561; J.-J. Rousseau, "Jugement sur la paix perpétuelle”, in C.E. Vaughan (ed.), The Political Writings of Jean Jacques Rousseau - Edited from the Original Manuscripts and Authentic Editions, Vol. 1 (New York: Franklin, 1971), 388, written in 1756 and first published in 1782; and, H Sée., Les idées politiques en France au XVIIe siècle (Geneva: Slatkine, 1978), at pp. 297-298.

${ }^{269}$ F.H. Hinsley, supra, note 258, at p. 45 [emphasis added]. 
Furthermore, this period also marked the beginning of the systematization of the law of nations, ${ }^{270}$ deemed a "Protestant science" because of its leading advocates. ${ }^{271}$ As Dionisio Anzilotti explained, the 18th century "marks the passage of the fragmentary treatment of our science to its systematic treatment' ${ }^{272}$ One of the catalysts was the gathering of international agreements in collections, sparked by the expansion and intensification of treaties in Europe ${ }^{273}$ - in 1700, Jacques Bernard edited a Recueil des traitez de pai $x^{274}$ in four volumes; in 1726-1731, Jean Dumont published Corps universel diplomatique du droit des gens ${ }^{275}$ in eight volumes and later supplemented; and, in 1791, Georg Friedrich von Martens started the publication of his Recueil des principaux

${ }^{270}$ See A. Hurrell, "Vattel: Pluralism and Its Limits", in I. Clark and I.B. Neumann (eds.), Classical Theories of International Relations (London: Macmillan, 1996), 233, at p. 249, who wrote that Vattel "was writing at the time when international law was becoming increasingly formalized and collected together (for example the Abbé de Malbly's [sic] Droit Publique [sic] de L'Europe fondé sur les Traités published in 1747) and when there was a notable expansion in the laws of war (agreements on prisoners, on military hospitals, etc.)".

${ }^{271}$ See A. Nussbaum, supra, note 111, at p. 140: "In retrospect it appears that all the leading authors of the seventeenth and eighteenth centuries on international law were Protestants, a condition persisting during the first decades of the nineteenth century and causing in 1847 the first historiographer of international law, Kaltenborn, to declare international law 'a Protestant science'."

${ }^{272}$ D. Anzilotti, Cours de droit international, Vol. 1, Introduction - Théories générales (Paris: Sirey, 1929), at p. 5 [emphasis in original]; author's translation of: "marque le passage du traitement fragmentaire de notre sicence à son traitement systématique" [emphasis in original]. See also, generally,L. Oppenheim, “The Science of International Law: Its Task and Method" (1908) 2 American J. Int'l L. 313.

${ }^{273}$ A. Nussbaum, supra, note 111, at p. 139. See also C. Kaltenborn von Stachau, Kritik des Völkerrechts nach dem jetzigen Standpunkte der Wissenschaft (Leipzig: Mayer, 1847), at p. 62.

${ }^{274} \mathrm{~J}$. Bernard (ed.), Recueil des traitez de paix, de trêve, de neutralité, de suspension d'armes, de confédération, d'alliance, de commerce, de garantie, et d'autres actes publics: comme contracts de mariage, testaments, manifestes, declarations de guerre, \&c. faits entre les empereurs, rois, républiques, princes, \& autres puissances de l'Europe, \& des autres parties du monde, depuis la naissance de Jesus-Christ jusqu'à présent; servant à établir les droits des princes, et de fondement a l'histoire, 4 Vols. (Amsterdam: Henry and Boom; The Hague: Moetjens and van Bulderen, 1700).

275 J. Dumont, Corps universel diplomatique du droit des gens: contenant un recueil des traitez d'alliance, de paix, de treve, de neutralité, de commerce, d'échange de neutralité, de commerce, d'échange de protection \& de Guarantie, de toutes les conventions, transactions, pactes, concordats, \& autres contrats, qui ont été faits en Europe, depuis le regne de l'empereur Charlemagne jusques à présent; [et cetera], 8 Vols. (Amsterdam: Brunel, Wetsteins, Janssons Waesberge, L'Honoré and Chatelain; The Hague: Husson and Levier, 1726-1731). 
traités $^{276}$ originally in seven volumes and later supplemented.

In terms of scholarly works of international law, the end of the 17th century and the 18th century witnessed the first systemic treatises ${ }^{277}$ - Johann Wolfgang Textor, Synopsis iuris gentium, ${ }^{278}$ published in 1680; Cornelius van Bynkershoek, De dominio maris dissertatio, ${ }^{279}$ published in 1702, and De foro legatorum liber singularis, ${ }^{280}$ published in 1721; Gabriel Bonnot Abbé de Mably, Droit public de l'Europe, ${ }^{281}$ published in 1748; Johann Jakob Moser, Erste Grundlehren des jetzigen europäischen Völker-Rechts in Fridens- und Kriegs-Zeiten, ${ }^{282}$ published in 1778; Karl Gottlob Günther, Europäisches Völkerrecht in Friedenszeiten, ${ }^{283}$ published in 1787; and, Georg Friedrich von Martens, Précis du droit des gens moderne de l'Europe, ${ }^{284}$ published in 1789.

Substantially, not all of these authors followed Wolff's Ius Gentium Methodo ${ }^{285}$ and Vattel's Droit des Gens ${ }^{286}$ in embracing the so-called "enlightened"287 natural

${ }^{276}$ G.F. von Martens, Recueil des principaux traités d'alliance, de paix, de trêve, de neutralité, de commerce, de limites, d'échange \&c., conclus par les puissances de l'Europe: tant entre elles qu'avec les puissances et etats dans d'autres parties du monde, depuis 1761 jusqu'à présent I tiré des copies publiées par autorité, des meilleures collections particulières de traités, \& des auteurs les plus estimés (Gottingen, Germany: Dieterich, 1791-1801).

277 See P. Haggenmacher, supra, note 88, at p. 17, who made the following remark: "On vise moins ici la littérature spécialement consacrée à la discipline naissance du droit international, de Zouche à Moser, en passant par Rachel, Textor, Leibniz et Bynkershoek; ce sont là plutôt des reflets que les monteurs de ce réaménagement de l'espace juridique." See also D. Anzilotti, supra, note 272 , at pp. 12-13.

278 J.W. Textor, Synopsis iuris gentium (Basel: Rüdinger, 1680).

${ }^{279}$ C. van Bynkershoek, De domini maris dissertatio, in C. van Bynkershoek, Opera minora, 2nd ed. (Leyden: Kerckhem, 1744), 351.

${ }^{280}$ C. van Bynkershoek, De foro legatorum liber singularis, in C. van Bynkershoek, Opera minora, 2nd ed. (Leyden: Kerckhem, 1744), 425.

${ }^{281}$ G.B. Mably, Droit public de l'Europe fondé sur les traités, 2 Vols. (Geneva: n.b., 1748).

${ }^{282}$ J.J.Moser, Erste Grundlehrendes jetzigen europäischen Völker-Rechts in Fridens- und KriegsZeiten (Nuremberg: Raspe, 1778).

${ }^{283}$ K.G. Günther, Europäisches Völkerrecht in Friedenszeiten, nach Vernunft, Verträgen und Herkommen: mit Anwendung auf die teutschen Reichsstände, 2 Vols. (Altenburg: Richterschen Buchhandlung, 1787-1792).

${ }^{284}$ G.F. von Martens, Précis du droit des gens moderne de l'Europe fondé sur les traités et l'usage: auquel on a joint la liste des principaux traités conclus depuis 1748, jusqu'à présent, avec l'indication des ouvrages où ils se trouvent, 2 Vols. (Gottingen: Dieterich, 1789).

${ }^{285}$ See supra, note 47.

${ }^{286}$ In the preface of Droit des Gens, Vattel refers to the contributions made to the science of natural law by Grotius, Hobbes, Pufendorf, and Barbeyrac: see Droit des Gens, Vol. 1, at pp. viii-xi; and also Law of Nations, at pp. viii-x. See also F.S. Ruddy, supra, note 109, at pp. 60-65. 
law, ${ }^{288}$ inherited from the 17 th century ${ }^{289}$ (Grotius in De Ius Belli ac Pacis, ${ }^{290}$ Hobbes in Leviathan, and Pufendorf in De Iure Naturae). However, even those who favoured a more empirical and positivist method to study the law of nations ${ }^{291}-$ like Moser and

${ }^{287}$ See A.P. d'Entrèves, supra, note 71, at pp. 48-62, who distinguished between the "natural law" of the medieval Scholasticism from the "naturalrights" of the Englightenment, and identified Grotius as the first proponent of the new school; see also A.-H. Chroust, "Hugo Grotius and the Scholastic Natural Law Tradition" (1943), 17 New Scholasticism 101; and, D.M. MacKinnon, "Natural Law", in H. Butterfield and M. Wight (eds.), Diplomatic Investigations-Essays in the Theory of International Politics (London: Allen and Unwin, 1966), 74. On the other hand, see L. Strauss, Natural Right and History, Chicago: University of Chicago Press, 1953), who separated the naturalists in the group of the classic school of natural law, in which falls Grotius, and the group of egalitarian or rationalistic school of natural law, in which fall Hobbes and Locke; see also P.P. Remec, supra, note 58, at pp. 45-54.

${ }^{288}$ See A. Nussbaum, supra, note 111, at pp. 134-135: "The natural-law school in the eighteenth-century science of international law is represented mainly by the German Christian Wolff in whom early Enlightenment strangely fuses with outdated scholasticism (infra, pp. 148-155). In his disciple, the Latin-Swiss Vattel, the traits of the Enlightenment are more marked (infra, pp. 155-163)." See also A.S. Hershey, "History of International Law Since the Peace of Westphalia” (1912), 6 American J. Int'1 L. 30, at pp. 37-38. As well, on how Wolff and Vattel followed the natural school, see E. Jouannet, supra, note 18, at pp. 85-100.

${ }^{289}$ See L. le Fur, "La théorie du droit naturel depuis le XVIIe siècle et la doctrine moderne" (1927), 18 R.C.A.D.I. 259, at p. 295 ff.; J.-P.-A. François, "Règles générales du droit de la paix" 66 R.C.A.D.I. 1, at pp. 11-13; C. Rousseau, Principes généraux du droit international public, Vol. 1, Introduction - Sources (Paris: Pedone, 1944), at pp. 17-23; T. Ruyssen, Les sources doctrinales de l'internationalisme, Vol. 2, De la Paix de Westphalie à la Révolution française (Paris: Presses universitairesde France, 1957), at pp. 191-216;E.B.F. Midgley, The Natural Law Tradition and the Theory of International Relations (London: Elek, 1975), at pp. 132-174; A. Brimo, Les grands courants de la philosophie du droit et de l'État, new ed. (Paris: Pedone, 1978), at pp. 95-105; M. Thomann, "Réalités et mythes du droit naturel en Europe vers 1789" (1988) 6 Rev. d'histoire 63; S. Goyard-Fabre, "L'hésitation conceptuelle du jusnaturalisme de Hobbes à Wolff' (1989), 8 Rev. d'histoire 51; and, E. Jouannet, id., at pp. 17-29.

${ }^{290}$ H. Grotius, De Iure Belli ac Pacis Libri Tres. In quibus ius naturae \& gentium: item iuris publici praecipua explicantur (Paris: Buon, 1625). See also the French translation from the notes of J. Barbeyrac, H. Grotius, Le Droit de la Guerre et de la Paix, 2 Vols. (Amsterdam: Pierre de Coup, 1724); and, the English translation by F.W. Kelsey, The Law of War and Peace, 2 Vols. (Indianapolis, U.S. and New York: Bobbs-Merrill, 1925).

On Grotius, in general, see E. Dumbauld, The Life and Legal Writings of Hugo Grotius (Norman, U.S.: University of Oklahoma Press, 1969); and, A. Dufour, "Grotius - Homme de loi, homme de foi, homme de lettres", in A. Dufour, P. Haggenmacher and J. Toman (eds.), Grotius et l'ordre juridique international (Lausanne: Payot, 1985), 9.

${ }^{291}$ See A.S. Hershey, supra, note 288, at pp. 34-36; E.D. Dickinson, supra, note 190, at pp. 250253; A. Nussbaum, supra, note 111, at p. 135; T. Ruyssen, supra, note 189, at pp. 208-215 and 
von Martens, who wrote along the line of Richard Zouche ${ }^{292}$ and Samuel Rachel ${ }^{293}-$ could not but be influenced by the naturalist school of thought, ${ }^{294}$ still overwhelming present in the 18th century intellectual circles. ${ }^{295}$ Thus the direct filiation between natural law and international law can hardly be doubted. ${ }^{296}$ Indeed, as Henry Maine wrote: "The grandest function of the Law of Nature was discharged in giving birth to modern International Law". 297

515-520; and, A. Anghie, "Finding the Peripheries: Sovereignty and Colonialism in NineteenthCentury International Law” (1999), 40 Harvard Int'l L.J. 1, at pp. 11-12.

${ }^{292}$ See R. Zouche, Iuris et Iudicii fecialis, sive, Iuris inter Gentes, et quaestionum de eodem explicatio (Oxford: n.b., 1650). Although Zouche's doctrine was very much linked to natural law, his law of nations consisted mainly of unwritten customary rules and written conventional principles. See also E. Jouannet, supra, note 18, at pp. 74-76.

${ }^{293}$ See S. Rachel, De Iure Naturae et Gentium Dissertationes (Kiel: Reumann, 1676). Rachel was also quite positivist, holding that international law develops by the express or tacit consent of nations; yet the obligatory nature of his system was ultimately founded, like Grotius, on natural law. See also E. Jouannet, id., at pp. 81-85.

On natural law and its authority in relation to the law of man, Grotius famously opined that natural law would exist even if there was no god - "What we have been saying would have a degree of validity even if we should concede that which cannot be conceded without the utmost wickedness, that there is no God, or that the affairs of men are of no concern to Him"; The Law of War and Peace, Vol. 1, supra, note 290, at p. 13.

${ }^{294}$ As P. Hazard, supra, note 241, at p. 145, theatrically wrote: "Haste, then, to work! Garner in the fruits of the ground won by Grotius, Pufendorf, Cumberland, Leibniz and Gravina. Let all Europe, nay, all the world, understand, at long last, that there is but one law, one original law, whence all others have their source, and that law is the Law of Nature." See also R. Derathé, Jean-Jacques Rousseau et la science politique de son temps (Paris: Presses universitaires de France, 1950), at p. 28.

As well, it is interesting to draw a parallel between natural law and the 18th century developments in physics, principally with Newton's work: "The Newtonian conception of physical law was projected into the spheres of legal and political philosophy. The notion of 'natural law' as the rule of the Creator, imposed upon the universe, was frequently tangled up with the current conceptions of the law of nature"; see J.S. Reeves, "The Influence of the Law of Nature upon International Law in the United States" (1909), 3 American J. Int'1 L. 547, at p. 550.

${ }^{295}$ See F.S. Ruddy, supra, note 109, at p. 56: "The 'kind of truth' that the eighteenth century would demand was that which conformed to natural law principles. That is, the underlying presumption of the age was that those thing which are in accordance with natural law, and which can be demonstrated to be such, are for that reason enjoined or forbidden. Therefore, a system of the law between States would have to be based, and demonstrably so, on natural law principles."

${ }^{296}$ See J.L. Brierly, supra, note 111, at pp. 16-25.

${ }^{297}$ H.S. Maine, Ancient Law - Its Connection with the Early History of Society, and its Relation to Modern Ideas, 5th ed. (New York: Holt, 1875), at p. 92. 
Therefore, the relatively stable political situation of 18th-century Europe, which had a tangible beneficial social impact of the affected populations, was very much the result of the healthy interplay of the three core principles of raison d'état, aggrandisement, and balance of power. Further, there was growing acknowledgement of a European commonality in terms of culture, intelligentsia, and even people. This enthusiasm, however, this did not translate into the acceptance of world federation proposals, mainly because of the emerging, yet already prominent, international relations system based on the ideas of State and sovereignty. As well, the systematization debut of the law of nations as a scientific discipline showed that, along with the still dominant enlightened natural law school, new perspectives based on the practice of State and the realities of their rapports were gaining ground. ${ }^{298}$

It is in this context that Vattel wrote Droit des Gens and announced its mission as follows: "The Law of Nations, though so noble and important a subject, has not, hitherto, been treated of with all the care it deserves". ${ }^{299}$ His treatise aimed at remedying this shortcoming. ${ }^{300}$ The audience that Vattel targeted was also quite explicitly put ${ }^{301}-$ "The law of nations is the law of sovereigns. It is principally for them and for their

${ }^{298}$ See M. Koskenniemi, “Theory: Implications for the Practitioner”, in P. Allott et al. (eds.), Theory and International Law: An Introduction (London: British Institute of International and Comparative Law, 1991), 1, at p. 28, who made the following point: "What these representatives of Enlightenment jurisprudence sought to achieve was precisely a distinction between themselves and their classical predecessors without having to ratify whatever it was sovereigns wished to do. They defined voluntary law to consist of the interpretations and 'modifications' which States have introduced into necessary natural law in order to apply it in practice. It was subjectively based and thus avoided the accusation of abstract utopianism (which Vattel threw at Berbeyrac, Hobbes and Grotius). But it was not apologist, either, as it was still natural law and maintained its connection with an objectively constraining morality. It was a mediating device to avoid, partially and temporarily, the immediate objections that contemporaries (and successors) directed upon pure naturalism (too objective) and pure positivism (too subjective)."

${ }^{299}$ Law of Nations, at p. vii. See also Droit des Gens, Vol. 1, at p. v.

${ }^{300}$ Vattel added: "The greater part of mankind have, therefore, only a vague, a very incomplete, and often even a false notion of it. The generality of writers, and even celebrated authors, almost exclusively confine the name of 'Law of Nations' to certain maxims and treatises recognized among nations, and which the mutual consent of the parties has rendered obligatory on them. This is confining within very narrow bounds a law so extensive in its own nature, and in which the whole human race are so intimately concerned; it is, at the same time, a degradation of that law, in consequence of a misconception of its real origin"; Law of Nations, at p. vii. See also Droit des Gens, Vol. 1, at p. v.

${ }^{301}$ See P. Guggenheim, supra, note 18, at p. 12, who wrote: “L'ouvrage de Vattel était destiné aux hommes d'Etats et aux diplomates, en un mot aux professionnels des affaires étrangères. Il ne devait pas seulement leur 'dire' le droit; l'ambition de Vattel allait plus loin: il se flattait d'exercer une influence sur les hommes d'Etat et de les amener à respecter ce droit international dont trop souvent ils font fi." See also E. Jouannet, supra, note 18, at p. $409 \mathrm{ff}$. 
ministers, that it ought to be written". ${ }^{302}$ Although every citizen may be interested, it is the persons entrusted with public affairs who should "apply seriously to the study of a science which ought to be their law, and, as it were, the compass by which to steer their course"; $; 03$ and if they did, Vattel added, "what happy effects might we not expect from a good treatise on the law of nations[?]"304

\section{Conclusion}

The inquiry into the history of the social effects of "sovereignty" in Droit des Gens shows that Vattel utilized and changed the word at hand for a particular purpose, namely, to attempt the externalization of the ruler's power by providing for the exclusivity of authority without as well as within. This objective was carried out with the fiction of the juridical person, absorbing individuals forming society, that enjoys the exclusive power among other internal authorities, but more significantly among other public authorities outside (that is, other nations) to represent and rule the people within the territory and in their relations with foreign States and individuals, that is, without the interference of other nations and without the submission to a higher legal order. Accordingly, the State was the sole holder of ultimate authority in a society of States and represented the reality of the incorporated independent power, as opposed to the reality of the personal interconnected power.

${ }^{302}$ Law of Nations, at p. xvi. Also Droit des Gens, Vol. 1, at p. xxiii. At the beginning of the second book, Vattel reiterated that he writes for the conductors of States: "And why should we not hope still to find, among those who are at the head of affairs, some wise individuals who are convinced of this great truth, that virtue is, even for sovereigns and political bodies, the most certain road to prosperity and happiness? There is at least one benefit to be expected from the open assertion and publication of sound maxims, which is, that even those who relish them the least are thereby laid under a necessity of keeping within some bounds, lest they should forfeit their characters altogether. To flatter ourselves with the vain expectation that men, and especially men in power, will be inclined strictly to conform to the laws of nature, would be a gross mistake; and to renounce all hope of making impression on some of them, would be to give up mankind for lost", Law of Nations, at p. 134. See also Droit des Gens, Vol. 1, at p. 257. Vattel comes back to this theme in his concluding remarks: Law of Nations, at p. 500; and also Droit des Gens, Vol. 2, at p. 375.

${ }^{303}$ Law of Nations, at p. xvi. See also Droit des Gens, Vol. 1, at p. xxiii.

${ }^{304}$ Law of Nations, at p. xvi; in Chitty's translation, the question mark is mistaken for an exclamation mark - see the original French Droit des Gens, Vol. 1, at p. xxiii: "quels fruits ne pourraiton attendre d'un bon Traité du Droit des Gens?" [spelling modernized].As well, see A. Mallarmé, supra, note 19, at p. 582, who wrote about Droit des Gens that, "il est un manuel de politique, une encyclopédie pratique et positive à l'usage des hommes publics" [emphasis added]. See also J.L. Brierly, supra, note 111, at p. 37; and, A. de Lapradelle, supra, note 22, at p. xxvii. 
Unlike many of his predecessors on the law of nations, ${ }^{305}$ Vattel wrote in his "vernacular language-of-State ${ }^{\$ 306}$ (as opposed to Latin), namely French, ${ }^{307}$ already then the diplomatic language of the time. ${ }^{308}$ This is said to explain in part the popularity of Droit des Gens, ${ }^{309}$ along with the general readability of its prose, the systematic presentation of the arguments, and the relevance of the work to the contemporary affairs. ${ }^{310}$ The last

${ }^{305}$ One only has to think of the works by Vitoria, Grotius, Pufendorf.

${ }^{306}$ This is an expression borrowed from B. Anderson, Imagined Communities (London and New York: Verso, 1983).

${ }^{307}$ On the influence of French all over Europe, see F.S. Ruddy, "The Acceptance of Vattel”, in C.H. Alexandrowicz (ed.), Grotian Society Papers 1972 (The Hague: Martinus Nijhoff, 1972), 176, at p. 181, who explained: "The languages of Europe matured or were maturing in the eighteenth century. Europe was the literary dominion of France, and it exerted its influence everywhere. The French style was simplicity and clarity, and where the native language had matured, as in England, it influenced it. Where the language had not developed, as in Russia, it filled the gap" [footnotes omitted].

${ }^{308}$ See A. Nussbaum, supra, note 111, at p. 127, who wrote that, in the 18 th century, "French was retained as the prevailing diplomatic language". He later opined that the use of the vernacular, "is characteristic of an ascendant trend in the internationallaw literature of the second half of the century"; id., at p. 138. See also E.L. Jones, The European Miracle-Environments, Economies and Geopolitics in the History of Europe and Asia, 2nd ed. (Cambridge: Cambridge University Press, 1987), at p. 112: "Over and above its diplomatic uses, French became the language of the fashionable set, to the extent that Tsarist nobles preferred it to Russian. By the death of Louis XIV the French language had captured the high society of Europe in a way that French arms had failed to do, and faster even than it was taking over the provinces in France itself."

${ }^{309}$ See T. Ruyssen, supra, note 289, at p. 508: "La raison principale de ce succès est sans doute qu'il est le premier théoricien notoire du droit international qui se soit exprimé en français; Grotius, Zouch, Pufendorf avaient écrit en latin, Wolff en latin et en allemand; Vattel eut le mérite d'offrir aux lecteurs de la République des Lettres, qui lisaient tous la langue de Voltaire, un traité du droit des gens, clairement écrit, point trop volumineux ni surchargé d'érodution pédante." See also F.S. Ruddy, supra, note 307, at p. 194, who expressed the following view: "Vattel wrote in French rather than Latin because Latin would not reach the audiences he had in mind."

${ }^{310}$ See P.F. Butler, supra, note 158, at p. 57; and, P. Guggenheim, supra, note 18, at p. 12, who spoke of Droit des Gens, as "un exposé clair, lumineux, immédiatement accessible". See also A. Chrétien, Principes de droit internationalpublic (Paris: Chevalier-Marescq, 1893), at p. 58: "Le Droit des gens de Vattel, publié en français en 1758, bien qu'il ne soit trop souvent que la paraphrase de l'ouvrage de Wolff, dut à la clarté et à l'élégance du style dans lequel il était écrit un succès auquel on ne peut comparer que celui obtenu plus d'un sciècle auparavant par le traité de Grotius." As well, on this point, see A. Nussbaum, supra, note 111, at pp. 160-161; A. de Lapradelle, supra, note 22, at p. xxxv; and, A. Mallarmé, supra, note 19, at p. 483. Finally, see R.P. Ward, An Enquiry into the Foundation and History of the Law of Nations in Europe - From the Time of the Greeks and Romans to the Age of Grotius, Vol. 2 (London: Butterworth, 1795), 
feature is linked to the inductive nature of the method used by Vattel, with the numerous references to contemporary State practice. ${ }^{311}$ His approach was thus both descending and ascending ${ }^{312}$ - unlike the ones favoured by the authors referred to in his preface,,$^{313}$ who perhaps made excessive use of abstract deductions from general principles ${ }^{314}$ which was meant to help "persuade", the stated objective of the work. ${ }^{315}$

However, it is the unprecedented success of Droit des Gens during the 18th century and beyond $\mathrm{d}^{316}$ - especially in Great Britain and the United States of America ${ }^{317}$ - that

626, who compared Vattel with his predecessors and noted that, "he has throughly cleared them from the cumbrous ornaments which were supposed to adorn them, and has rendered the way into the interior less difficult and obscure" [spelling modernized].

${ }^{311}$ See C. Phillipson, supra, note 28, at p. 494, who pointed out that Vattel preferred contemporary cases over ancient ones: "He is above all a practical man, and therefore he abandons the stale precedents of the classical ages and uses modern instances of the clearest kind." See also A. de Lapradelle, supra, note 22, at pp. xxvii-xxviii; and, E. Jouannet, supra, note 18, at pp. 133-140.

312 See P.P. Remec, supra, note 58, at p. 189: "Actually, he roughly adapted the extent of his analogicaldeductions to the empirically observed practice of nations of his time. By this process he gave to the more acceptable principles of contemporary practice the respectable and fashionable cloak of a universally binding rational rule in contrast to the practices which he personally abhorred and therefore effectively branded as illegal and irrational. The wide acceptance of Vattel's doctrine is due exactly to these reasons" [footnotes omitted].

${ }^{313}$ In the preface of Droit des Gens, Vattel made references to Grotius, Hobbes, Pufendorf, Barbeyrac, and especially Wolff.

${ }^{314}$ See M. Koskenniemi, supra, note 186, at p. 89.

315 See Law of Nations, at p. xvi: "It is sufficient for me to persuade, and for this purpose to advance nothing as a principle that will not readily be admitted by every sensible man." See also Droit des Gens, Vol. 1, at p. xxiii. As F.S. Ruddy, supra, note 307, at p. 193, rightly pointed out, "To persuade one cannot be abstruse".

316 The number of editions and translations of Droit des Gens provides a good indication of the great success and influence of Vattel. Between 1758 and 1863, there were twenty editions of the work in its original language, French. In Great Britain, there were ten English translations between 1759 and 1834; in the United States of America, there were eighteen translations or reprints of translations between 1796 and 1872. His book was also translated into Spanish (six between 1820 and 1836), German (1760) and Italian (1805). See J.B. Scott (ed.), The Classics of International Law - Vattel, Vol. 1 (Washington: Carnegie Institution of Washington, 1916), at pp. 1viii-lix

317 See A. de Lapradelle, supra, note 22, at pp. xxvii-xlii, who provided a good summary of the information pertaining to the reception and authority of Droit des Gens in Great Britain and in the United States of America during the 18th and 19th centuries. See also J.S. Reeves, supra, note 294, at p. 549; C.G. Fenwick, supra, note 142, at pp. 406-410; A. Nussbaum, supra, note 111, at pp. 161-162;P. Guggenheim, supra, note 18, at pp. 15-16; T. Ruyssen, supra, 289, at pp. 514-515; and, E. Jouannet, supra, note 18, at pp. 14-15. 
best bears witness to the immense impact Vattel had on the shared consciousness of society with his use of the word "sovereignty". ${ }^{318}$ As Charles Fenwick succinctly explicated:

Vattel's treatise on the law of nations was quoted by judicial tribunals, in speeches before legislative assemblies, and in the decrees and correspondence of executive officials. It was the manual of the student, the reference work of the statesman, and the text from which the political philosopher drew inspiration. Publicists considered it sufficient to cite the authority of Vattel to justify and give conclusiveness and force to statements as to the proper conduct of a State in its international relations. ${ }^{319}$

This achievement may only be explained by recognizing that Droit des Gens provided legal and diplomatic answers to the current problems of international relations and

318 See H. Lauterpacht, "Les travaux préparatoires et l'interprétation des traités" (1927), 18 R.C.A.D.I. 709, at p. 713, who wrote: "Il n'est pas d'auteur dont le nom ait été plus fréquemment mentionné devant les tribunaux internationaux que Vattel."

Most interestingly,E.D. Dickinson, supra, note 190, at p. 259, note 132, compiled the number of times European internationalists were used before and by the Supreme Court of the United States at the turn of the 19th century (1879-1920), which shows how Vattel was ahead and had thus a real and comparatively great impact on human consciousness - "Eighty-two cases were found in these [seventeen] volumes involving more or less important questions of international law. The figures in parentheses indicate the number of instances in which the publicist name was cited, quoted, or paraphrased. Cited in argument: Grotius (16), Pufendorf (9), Bynkershoek (25), Burlamaqui (9), Rutherforth (18), Vattel (92). Cited in opinion: Grotius (11), Pufendorf (4), Bynkershoek (16), Burlamaqui (4), Rutherforth (5), Vattel (38). Quoted or paraphrased in opinion: Grotius (2), Bynkershoek (8), Burlamaqui (2), Rutherforth (2), Vattel (22)" [emphasis in original]. See also the compilation of arbitrationdecisions which cite Vattel made by E. Jouannet, supra, note 18, at p. 15, note 22, which is based on A. de Lapradelle and N. Politis (eds.), Recueil des artibrages internationaux (Paris: Pedone, 1923).

319 C.G. Fenwick, supra, note 142, at p. 395. See also G. von Glahn, Law Among Nations, 3rd ed. (New York: Macmillan, 1976), at p. 44: "It can seriously be maintained that despite the vital contribution of Grotius, no single writer has exercized as much direct and lasting influence on the men engaged in the conduct of international affairs in the legal sphere, at least until very modern times, as did Vattel."

It is also interesting to point out that even Vattel critics agreed that Droit des Gens received a phenomenal success; see, for instance, C. van Vollenhoven, supra, note 17, at p. 32; and, C. van Vollenhoven, Du droit de paix - De iure pacis (The Hague: Martinus Nijhoff, 1932), at pp. 9899. Other negative assessments of Vattel's work were made by A.G. Heffter, Le droit international de l'Europe, 4th ed. (Berlin: Müller; Paris: Cotillon, 1883), at p. 34; F. von Martens, supra, note 16, at pp. 211-212; W. Van der Vlugt, supra, note 16, at p. 467; and, J.L. Brierly, supra, note 111 , at p. 40. One must also point out Bentham's notorious quote - "Vattel's propositions are most old-womanish and tautological"; see the citation reproduced in E. Nys, "Notes inédites de Bentham sur le droit international”(1885), 1 L.Q. Rev. 225, at p. 230. 
governance ${ }^{320}$ which were along the lines of the core political principles and needs of the time. ${ }^{321}$ "It was a 'realistic' book," wrote Koskenniemi, "especially useful for diplomats and practitioners, not least because it seemed to offer such compelling rhetorics for the justification of most varied kinds of State action". ${ }^{322}$

As such, the word sovereignty has demonstrated, and has been strategically used by Vattel to carry, fabulous social power within the shared consciousness of humanity. ${ }^{323}$ Further, it has never stopped creating and transforming reality through the cognitive process of the human mind, as the socially constructed world evolved and changed over the years. For instance, Judge Anzilotti in the case of Austro-German Customs Union, spoke of "sovereignty (suprema potestas), or external sovereignty, by which is meant that the State has over it no other authority than that of international law". ${ }^{324}$

${ }^{320}$ Some contend that Vattel's success derived, at least in part, from the many ambiguities and
inconsistencies found in his work. See, for exemple, H. Lauterpacht, The Function of Law in the
International Community (Oxford: Clarendon Press, 1933), at p. 7, who referred to his "elegant
manner of evasion"; and, A. Nussbaum, supra, note 111, at p. 159, who spoke of "the striking
ambiguity of his formulas and [...] the inconsistency of many of his conclusions." See also M.
Wight, "Western Values in International Relations", in H. Butterfield and M. Wight (eds.), Dip-
lomatic Investigations - Essays in the Theory of InternationalPolitics (London:Allen and Unwin,
1966), 89, at p. 119, who wrote that, "it is part of his charm (and no doubt of his lasting influence)
that he contains inconsistent arguments that can be used to support contradictory policies".

${ }^{321}$ See P.P. Remec, supra, note 58, at p. 56, who explained thus: "Vattel's system of international law received through this synthesis a very 'modern' form, primarily because it fitted actual contemporary practice so well, which it sought to justify in high moral terms." See also P.F. Butler, supra, note 158, at p. 57: "Vattel, I suggest, recognized the major components of political life that were identified in eighteenth-century Europe: the sovereign, the individual, the transnational moral order, and property. He also dealt with these components in a way that settled their relative moral significance. Acceptance of the general thrust of his arguments contributed to the maintenance of the balance of power system."

${ }^{322}$ M. Koskenniemi, supra, note 186, at p. 89 [emphasis added]. See also J.S. Reeves, "La communauté internationale"(1924), 3 R.C.A.D.I. 1, at pp. 37-38; and, F.S. Ruddy, supra, note 307, at pp. 194-195.

${ }^{323}$ See J.L. Brierly, "Règles générales du droit de la paix” (1936), 58 R.C.A.D.I. 1, at pp. 24-25, who forcefully made this very point: "Celle-ci [sovereignty]à aucune période de son histoiren'a été une déduction scientifique dérivée de l'examen de la nature essentielle de l'autorité politique; pratiquement, chaque théoricien de cette question a eu un but de propagande et non un but simplement scientifique. Ainsi, Bodin était convaincu de la nécessité de renforcer l'autorité centralisée du roi de France; Hobbes était épouvanté par les bouleversements civils au milieu desquels il avait vécu; Locke voulait défendre une révolution; Rousseau, soutenir les droits de la démocratie" [emphasis added].

${ }^{324}$ Austro-German Customs Union case (1931), P.C.I.J., series A/B, no. 41, at p. 57, [emphasis in original] in a separate opinion. 
Furthermore, the association of the words "sovereignty" and "independence" ${ }^{\text {"325 }}$ found in Vattel's Droit des Gens ${ }^{326}$ has been maintained to this day by a large number of international publicists. ${ }^{327}$ For instance, Ian Brownlie wrote: "The term 'sovereignty' may be used as a synonym for independence, an important element in statehood". ${ }^{328}$ Anthony Carty noted: "For the international lawyer, then, sovereignty equals independence and consists of the bundle of competences which have not already been transferred through the exercise of independent consent to an international legal order". ${ }^{329}$ In the Island of Palmas case, Arbitrator Huber declared: "Sovereignty in the relations between States signifies independence. Independence in regard to a portion

${ }^{325}$ Independenceconstitutes one of the formal requirements for a State to be recognized as such; see the Convention on Rights and Duties of States, 165 L.N.T.S. 19, signed in Montevideo on 26 December 1933, which is generally deemed to encapsulate the so-called criteria of Statehood, although "it is no more than a basis for further investigation", as I. Brownlie, Principles of Public International Law, 4th ed. (Oxford: Clarendon, 1990), at p. 72, rightly pointed out. See also J. Crawford, "The Criteria for Statehood in InternationalLaw" (1976-1977), 48 British Y.B. Int'l L. 93.

${ }^{326}$ See A. Hurrell, supra, note 270, at pp. 233-234, who wrote: "Finally, for many international lawyers, it is Vattel's emphasis on the absolute independence of States that was the most significant characteristic of his writing - the 'principle of legal individualism' as Brierly labels it - a characteristic widely applauded in the nineteenth century but increasingly criticized in this century" [emphasis added] [footnotes omitted].

327 See, among many authors, J.E.S. Fawcett, "General Course on Public International Law" (1971), 132 R.C.A.D.I. 363, at p. 381 ff.; O. Beaud, supra, note 61, at pp. 128-132; and, P. Daillier and A. Pellet (eds.), Nguyen Quoc Dinh - Droit international public, 5th ed. (Paris: LGDJ, 1994), at pp. 409-410. See also, to the same effect, the opinion of the Soviet international commentator S. Krylov, "Les notions principales du droit des gens (La doctrine soviétique du droit international)"(1947), 70 R.C.A.D.I. 407, at p. 451.

An author has even advocated to substitute sovereignty by independence, see R.R. Foulke, $A$ Treatise on International Law (Philadelphia: Winton, 1920), at p. 69: "The word sovereignty is ambiguous. [...] We propose to waste no time in chasing shadows, and will therefore discard the words entirely. The word 'independence' sufficiently indicates every idea embraced in the use of sovereignty necessary to be known in the study of international law.' For his part, Koskenniemi, supra, note 186 , at p. 209 , pointed out that replacing sovereignty by independence is really to substitute one ambiguous expression for another.

328 I. Brownlie, supra, note 325, at p. 78.

${ }^{329}$ A. Carty, "Sovereignty in International Law: A Concept of Eternal Return", in L. Brace and J. Hoffman (eds.), Reclaiming Sovereignty (London and Washington: Pinter, 1997), 101, at p. 101 [emphasis added]. See also C. Parry, "The Function of Law in the International Community”, in M. Sørensen (ed.), Manual of Public InternationalLaw (London: Macmillan, 1968), 1, at p. 13, who opined that, in international law, "sovereignty no longer conveys the idea of supremacy but rather that of independence". 
of the globe is the right to exercise therein, to the exclusion of any other State, the functions of a State". ${ }^{330}$

This illustrates the modern history of the true power that "sovereignty" has exercised in framing the international State system and hence the international legal system. Like the word itself, therefore, the creative and transforming function of sovereignty is continuous and continuing, changing in its nature and effects over time. Fundamentally, the vision Vattel had of international law has been dominant ever since the publication of Droit des Gens, ${ }^{331}$ and has remained thus to this day in spite of the recent organizational and institutional developments on the international plane. ${ }^{332}$ In international legal terms, the world is indeed still essentially a society of sovereign States that are "independent", that is, free from foreign intervention or constraining rule of law.

${ }^{330}$ Island of Palmas case (1928), 2 R.I.A.A. 829, at p. 838 [emphasis added]. See also, on the territorial dimension of sovereignty, the arbitration case of the North Atlantic Coast Fisheries (1910), 11 R.I.A.A. 167, at p. 180; and, the Corfu Channel (Merits) case, [1949] I.C.J. Reports 2 , at p. 35 .

${ }^{331}$ See J. Huntzinger, Introduction aux relations internationales (Paris: Seuil, 1987), at pp. 3637. See also G. Scelle, "Règles générales du droit de la paix" (1933) 46 R.C.A.D.I. 327, at p. 331.

332 This socially constructed model, however, has long been challenged by intellectuals around the world, and never more vigorously than now, in the era of the so-called "globalization" or "mondialisation", which calls more than ever for a new legal order that corresponds better to the contemporary reality. See, among many international publicists on this, O. Schachter, "Sovereignty - Then and Now", in R.St.J. Macdonald (ed.), Essays in Honour of Wang Tieya (Dordrecht: Martinus Nijhoff, 1994), 671, at p. 671; and, most recently, P. Allott, "The Emerging Universal Legal System" (2001), 3 Int'1 L. Forum 12, at p. 17, who opined: "International social reality has overtaken international social philosophy. The Vattelian mind-world is withering away under the impact of the new internationalsocial reality. The reconstructionof the metaphysicalbasis of international law is now well advanced. The deconstruction of the false consciousness of politicians, public officials, and international lawyers is only just beginning" [emphasis added]. 